\title{
A comprehensive review on the applications of coal fly ash
}

\author{
Z.T. Yao ${ }^{\text {a }}$, X.S. Ji ${ }^{\text {b, } *}$, P.K. Sarker ${ }^{\text {c }}$, J.H. Tang ${ }^{\text {a,* }}$, L.Q. Ge ${ }^{\text {b }}$, M.S. Xia ${ }^{\text {b }, ~ Y . Q . ~ X i ~}{ }^{\text {a,d }}$ \\ a College of Materials Science and Environmental Engineering, Hangzhou Dianzi University, Hangzhou 310018, China \\ b Ocean College, Zhejiang University, Hangzhou 310058, China \\ c Department of Civil Engineering, Curtin University of Technology, Perth, WA 6845, Australia \\ ${ }^{\mathrm{d}}$ Research Center of Analysis and Test, East China University of Science and Technology, Shanghai 200237, China
}

\section{A R T I C L E I N F O}

\section{Article history:}

Received 2 February 2014

Accepted 5 November 2014

Available online 10 December 2014

\section{Keywords:}

Coal fly ash

Global level

Comprehensive utilization

Valorization

Soil amelioration

Mode of utilization

\begin{abstract}
A B S T R A C T
Coal fly ash, an industrial by-product, is derived from coal combustion in thermal power plants. It is one of the most complex anthropogenic materials, and its improper disposal has become an environmental concern and resulted in a waste of recoverable resources. There is a pressing and ongoing need to develop new recycling methods for coal fly ash. The present review first describes the generation, physicochemical properties and hazards of coal fly ash at the global level, and then focuses on its current and potential applications, including use in the soil amelioration, construction industry, ceramic industry, catalysis, depth separation, zeolite synthesis, etc. Finally, the advantages and disadvantages of these applications, the mode of fly ash utilization worldwide and directions for future research are considered.
\end{abstract}

(c) 2014 Elsevier B.V. All rights reserved.

\section{Contents}

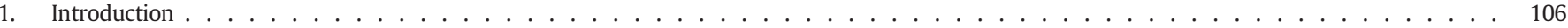

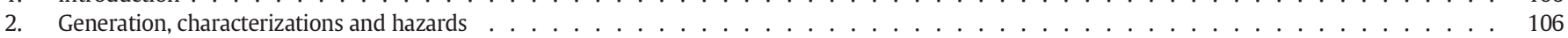

2.1. Global generation . . . . . . . . . . . . . . . . . . . . . . . . . . . . 106

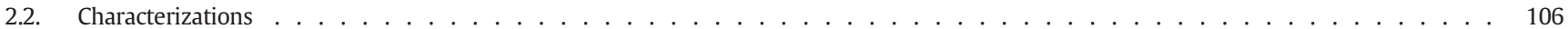

2.3. Hazards . . . . . . . . . . . . . . . . . . . . . . . . . . . . . . . . . . 107

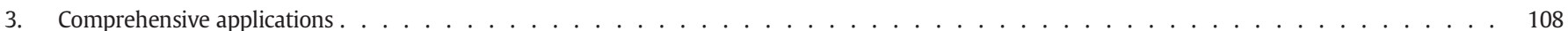

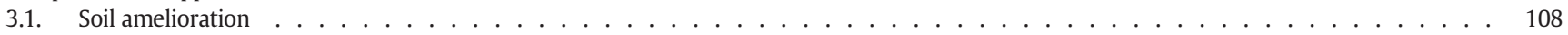

3.2. Construction industry . $\ldots \ldots$

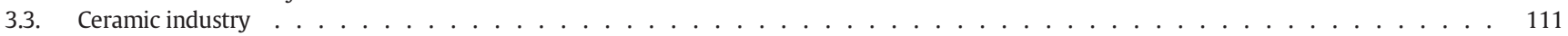

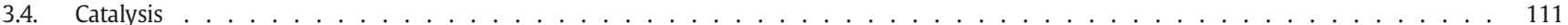

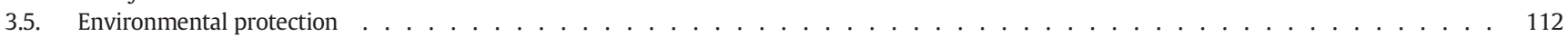

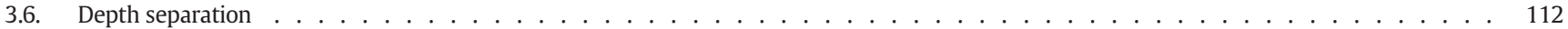

3.7. Zeolite synthesis . . . . . . . . . . . . . . . . . . . . . . . . . . . . . . . . . . . . . . . . . 113

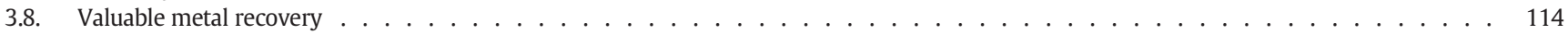

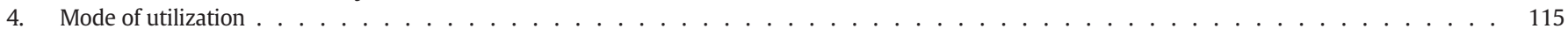

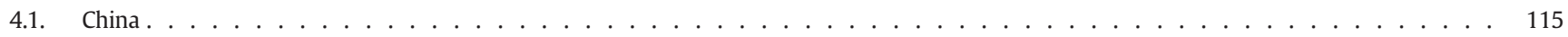

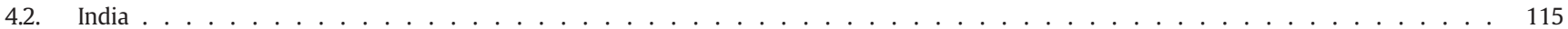

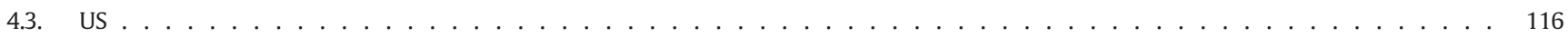

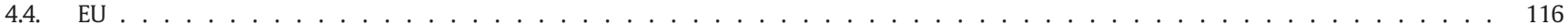

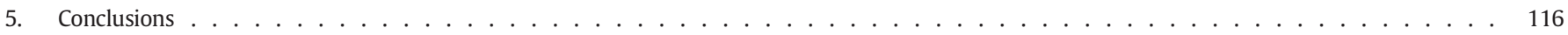

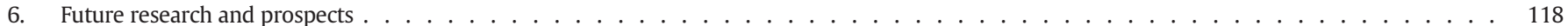

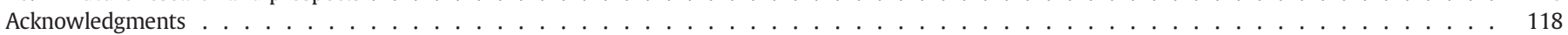

References $\ldots$

\footnotetext{
* Corresponding authors. Tel./fax: + 8657186919158.

E-mail addresses: jixiaoshen@hotmail.com, sxyzt@126.com (X.S. Ji), tang_jhjh@163.com (J.H. Tang).
} 


\section{Introduction}

Coal fly ash, a by-product of coal combustion in thermal power plants, is one of the most complex and abundant of anthropogenic materials. If not properly disposed of, it can cause water and soil pollution, disrupt ecological cycles and pose environmental hazards. More aggressive efforts have been undertaken recently to recycle fly ash (Temimi et al., 1995; Ilic et al., 2003). For example, about $20 \%$ of the fly ash generated is being used in concrete production. Other uses include road base construction, soil amendment, zeolite synthesis, and use as a filler in polymers (Cho et al., 2005). However, these applications are not sufficient for the complete utilization of the fly ash generated. The remainder is waste, and has to be discharged into ash ponds, lagoons or landfills. In the future, more stringent disposal siting restrictions, shrinking availability of landfill space and escalating disposal costs are anticipated, thereby it is imperative to develop new recycling techniques for coal fly ash. Recent review such as Ahmaruzzaman (2010) presented the details on properties of coal fly ash and its various possible applications. There are also other reviews on the fly ash utilizations from the perspectives of soil amelioration and mine reclaimation (Ram and Masto, 2010; Skousen et al., 2012; Ram and Masto, 2014), alumina and cenosphere recovery (Kolay and Bhusal, 2014; Yao et al., 2014), adsorbents for mercury removal, $\mathrm{CO}_{2}$ capture and wastewater treatment (Zheng et al., 2012; Wee, 2013), etc. However, some important and fundamental aspects, such as the generation of fly ash worldwide, and the modes of utilization are not considered. Thus, this review first attempts to investigate the fly ash generation in major countries (China, India and US), its physicochemical properties and hazards, and then focuses on its current and potential applications, including use in the soil amelioration, construction industry, ceramic industry, zeolite synthesis, catalysis, depth separation, etc. Finally, the advantages and disadvantages of these applications, the mode of ash utilization and directions for future research are considered. This paper will add to the further understanding of current utilizations of coal fly ash and identifying the promising applications.

\section{Generation, characterizations and hazards}

\subsection{Global generation}

Coal fly ash accounts for 5-20 wt.\% of feed coal and is typically found in the form of coarse bottom ash and fine fly ash, which represent 5-15 and 85-95 wt.\% of the total ash generated, respectively. Coal ash is discharged by both wet and dry methods of coal combustion. Bottom ash refers to the ash that falls down through the airflow to the bottom of the boiler and is mechanically removed (Jala and Goyal, 2006; Yao, 2013). The term fly ash, by contrast, is most often used to refer to fine fly ash, particles of which are captured from flue gas and collected by electrostatic or mechanical precipitation.

From the beginning of widespread electricity use, coal has fueled, and continues to fuel, the largest share of worldwide electric power production, and coal consumption has increased significantly over this period and is expected to continue increasing. In 2011, coal-fired generation accounted for $29.9 \%$ of the world electricity supply, and its share is anticipated to be $46 \%$ by 2030 . Sustained high prices for oil and natural gas make coal-fired generation more attractive economically, particularly in nations that are rich in coal resources, such as China, the US and India (Lior, 2010). China is the largest coal consumer in the world and accounts for $50.2 \%$ of the world coal consumption in 2012 . Rounding out the top 10 behind China, the US (11.7\%) and India (8\%), the followers were Japan (3.3\%), Russian Federation (2.5\%), South Africa (2.4\%), South Korea (2.2\%), Germany (2.1\%), Poland and Indonesia (1.4\%) (see Fig. 1). China's industrial growth depends on coal, which contributed to $68.49 \%$ of the total primary energy consumption in 2012 (see Fig. 2). The proportions were 20, 53, and 21.78\% for the

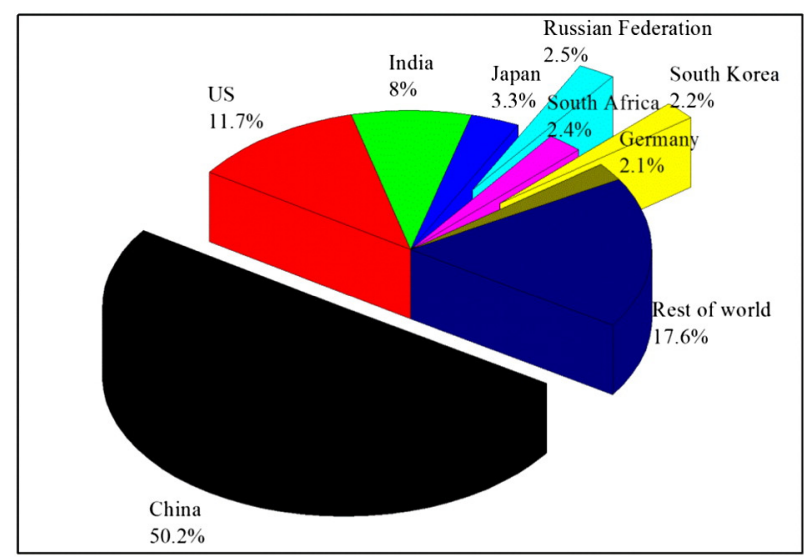

Fig. 1. Distribution of coal consumption worldwide in 2012.

US, India and Japan. Taking these data into account, a more up-to-date estimate of annual worldwide generation of fly ash is approximately 750 million tonnes (Blissett and Rowson, 2012; Izquierdo and Querol, 2012). Fig. 3 shows the generation and utilization of coal fly ash in China, the US and India. For China, the annual fly ash generation is still increasing and is anticipated to reach 580 million tonnes by 2015. According to the Central Electricity Authority (CEA) annual report on fly-ash generation-utilization, the fly ash generation and utilization in India were calculated and displayed in Fig. 3. It can be seen that approximately 160 million tonnes of fly ash is presently generated annually with a utilization rate of approximately 60\%. The American Coal Ash Association (ACAA) surveys and published data on the generation and utilization of coal combustion products (CCPs) including fly ash, bottom ash, boiler slag, flue gas desulfurization (FGD) gypsum, FGD material wet/dry scrubbers, FGD other and fluidized bed combustion (FBC) ash. According to the annual CCPs' Production and Use Survey Report released by the ACAA, the generation and utilization of fly ash, bottom ash, boiler slag and FBC ash were calculated. The present ash utilization in the US is approximately $50 \%$ and total generation is estimated to be around 130 million tonnes by 2015 .

\subsection{Characterizations}

Understanding the physical, chemical and mineralogical properties of coal fly ash is important, as these properties influence its subsequent use and disposal. The specific properties depend on the type of coal used, the combustion conditions, and the collector setup, among other factors. Physically, fly ash occurs as fine particles with an average size of $<20 \mu \mathrm{m}$ and has low to medium bulk density $\left(0.54-0.86 \mathrm{~g} / \mathrm{cm}^{3}\right)$, high surface area $\left(300-500 \mathrm{~m}^{2} / \mathrm{kg}\right.$ ) and light texture. The iron and unburnt carbon contents present influence the apparent color, which ranges from water-white to yellow, orange to deep red, or brown to opaque (Fisher et al., 1978). The $\mathrm{pH}$ values vary from 1.2 to 12.5 , with most ashes tending toward alkalinity (Kolbe et al., 2011). The pH value of the ash-water system depends mainly on the $\mathrm{Ca} / \mathrm{S}$ molar ratio in ash, although other minor alkalis or alkaline earth cations may also contribute to the balance (Ward et al., 2009; Izquierdoa and Querol, 2012). Based on the Ca/S ratio and $\mathrm{pH}$ value, fly ash can be classified into three main groups: strongly alkaline ash (pH 11-13), mildly alkaline ash ( $\mathrm{pH} \mathrm{8-9)}$ and acidic ash.

Micromorphology observation reveals that the fly ash particles are predominantly spherical in shape and consist of solid spheres, cenospheres, irregular-shaped debris and porous unburnt carbon (see Fig. 4). In FBC ash, spherical particles are rarely observed and most of the particles exhibit irregular shapes, primarily because most minerals in the coal do not undergo melting but soften only, under the relatively 

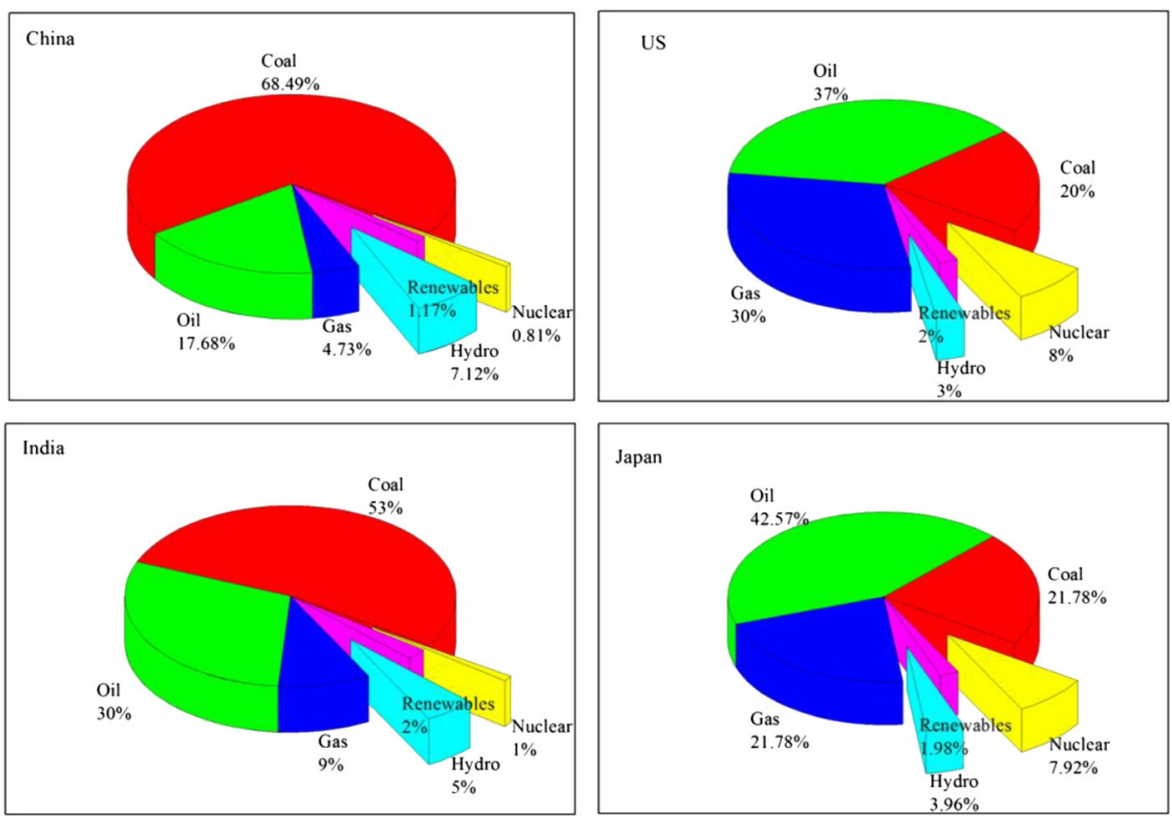

Fig. 2. Energy consumption by source worldwide in 2012 .

low boiler temperature of $850-900{ }^{\circ} \mathrm{C}$ (Lee et al., 1984; Seo et al., 2010). The irregular fragments consist mainly of unburnt carbon, anhydrate and calcite.

Coal fly ash is one of the most complex of the materials that can be characterized. Approximately 316 individual minerals and 188 mineral groups have been identified in various ash samples (Vassilev and Vassileva, 1997; Vassilev et al., 2003; Vassilev and Vassileva, 2005). The major components are metallic oxides with varying contents of unburnt carbon as measured by a loss on ignition (LOI) test. The contents of principal oxides are usually in a descending order: $\mathrm{SiO}_{2}>\mathrm{Al}_{2} \mathrm{O}_{3}$ $>\mathrm{Fe}_{2} \mathrm{O}_{3}>\mathrm{CaO}>\mathrm{MgO}>\mathrm{K}_{2} \mathrm{O}$. Fly ash also contains many trace elements, some of which are of environmental concern. Commonly, elements such as $\mathrm{Cr}, \mathrm{Pb}, \mathrm{Ni}, \mathrm{Ba}, \mathrm{Sr}, \mathrm{V}$ and $\mathrm{Zn}$ are present in significant quantities. Because of this, mobility and leaching studies have been conducted to assess the probability of these elements migrating to the environment (Fernández-Turiel et al., 1994; Ram et al., 2007a; Sarode et al., 2010).

\subsection{Hazards}

The environmental impact of coal fly ash has been fully recognized. Most ash disposal methods ultimately lead to the dumping of fly ash on open land. In some countries, coal fly ash is defined as a general solid waste and its treatment is not subject to regulation as a hazardous waste. Irregular accumulation and inappropriate disposal of fly ash will lead to its disposal over vast areas of land, with resultant degradation of the soil and danger to both human health and the environment. Fly ash particles, small enough to escape emission control devices, are easily suspended in air and have become a major source of gas pollution. Repeated exposure to fly ash can cause irritation of the eyes, skin, nose, throat and respiratory tract, and can even result in arsenic poisoning. Fly ash can even reach the sub-soil and ultimately cause siltation, clog natural drainage systems and contaminate the ground water with heavy metals.

Coal contains significant amount of various trace metals, and after combustion these metal concentrations in fly ash are sometimes 4-10 times higher than that of in parent coal. Coal fly ash has been viewed as a major potential source of releasing many environmentally sensitive elements to the environment. Many factors, such as the particle size, initial concentration of trace elements, $\mathrm{pH}$ of extraction solution, leaching time and solid/liquid ratio affect the mobility of the trace elements in aqueous environments (Saikia et al., 2006). Under favoring conditions, a considerable amount of these trace elements can easily be leached out from the surface of fly ash particles by the interaction with water in ponds or landfills (Bhattacharyya et al., 2009). The water-soluble trace elements contaminate the soil, surface and ground water (Choi et al., 2002; Sushil and Batra, 2006). It has been reported that the metal contaminants like $\mathrm{V}, \mathrm{Cr}, \mathrm{Ni}, \mathrm{Cd}$ and $\mathrm{Pb}$ are potential hazards to the environment even at low levels (Patra et al., 2012). Nyale et al. (2014) investigated the leaching behavior and geochemical partitioning of the trace elements $\mathrm{As}, \mathrm{Zn}, \mathrm{Pb}, \mathrm{Ni}, \mathrm{Mo}, \mathrm{Cr}$ and $\mathrm{Cu}$ in a 20 -year-old fly ash dump. The trace species readily leached from the dumped fly ash and thus it posed a threat to the air, surface and ground water, soil and crop produce. Neupane and Donahoe (2013) used batch and column leaching tests to evaluate the leachability of several elements (As, Co, Cr, Ni, Sb, Se, Ti, V, and Zn). The results showed that older unlined fly ash disposal sites could pose environmental risk of contamination. Effective containment methods were desirable for unlined/leaky disposal facilities.

Assessment of the radiation exposure from fly ash is critically dependent on the concentration of radioactive elements in the parent coal and in the fly ash that remains after combustion. During coal combustion, most of $\mathrm{U}$, Th and their decay products are released from the original coal matrix and are distributed between the gas phase and the solid combustion products. Mathur et al. (2008) investigated the Rn exhalation rates in fly ash samples in India and observed that the activity concentration of radionuclides was enhanced after coal combustion. Fly ash contains the radiochemical polluting elements of the $U$ and Th series, along with other radioactive contaminants like ${ }^{222} \mathrm{Ru}$ and ${ }^{220} \mathrm{Ru}$. Bhangare et al. (2014) measured the radioactivity of ${ }^{238} \mathrm{U},{ }^{226} \mathrm{Ra},{ }^{232} \mathrm{Th}$ and ${ }^{40} \mathrm{~K}$ for fly ash from six power plants across India. All the samples were found enriched with the radionuclides. Thus, it is important to monitor and regulate the release of this radioactivity to the environment. When the fly ash is utilized in purposes like construction materials, people are susceptible to be exposed to its radioactivity. Kovler (2012) investigated whether the utilization of coal fly ash in concrete construction presents a radiation hazard. The results showed that although radon exhalation rate of concrete containing coal fly ash can be sometimes slightly higher, radon emanation coefficient was lower. Also, the radioactivity concerns of the soil and crop produce due to fly ash application as soil ameliorant need to be considered. Tripathi 

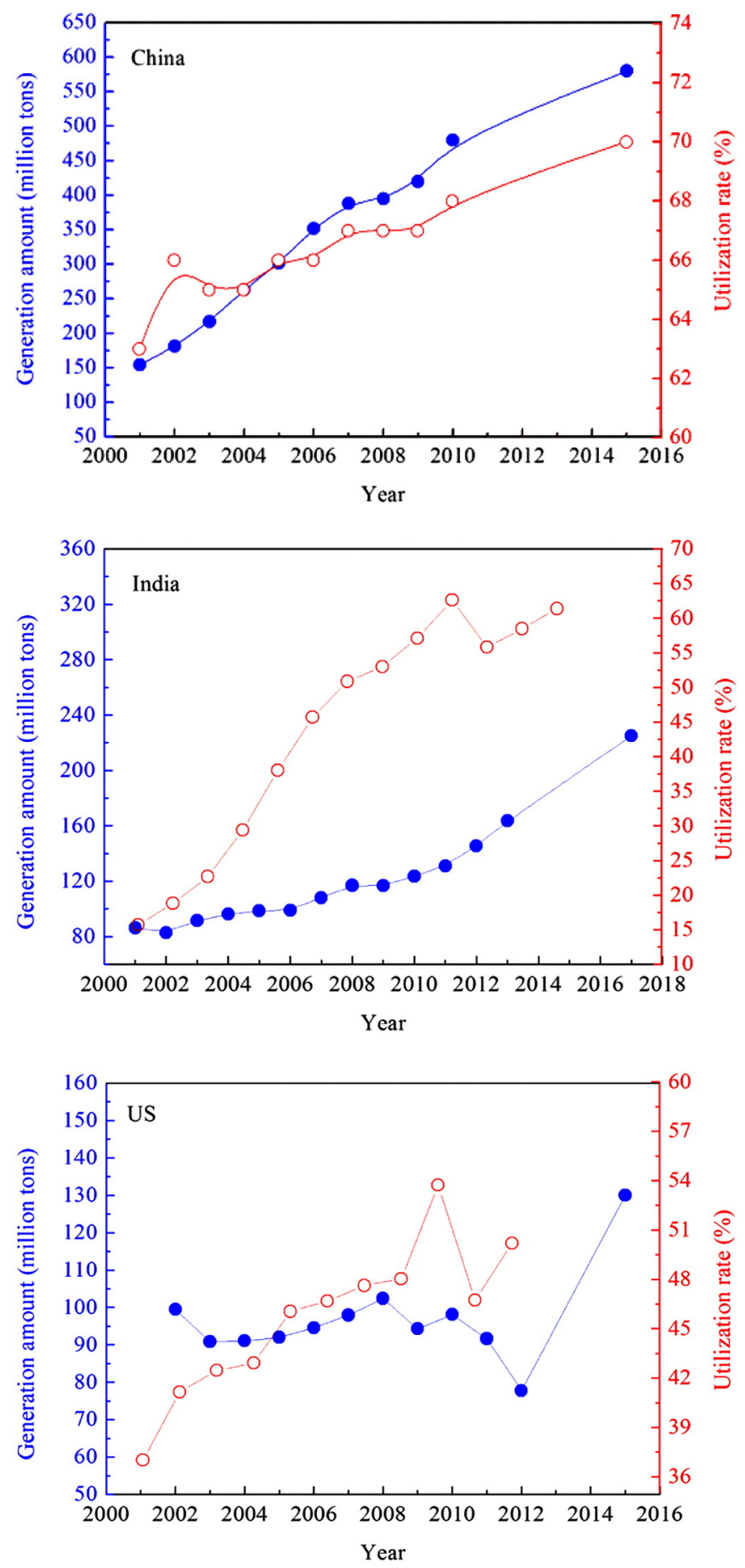

Fig. 3. The generation and utilization of coal fly ash worldwide (National Development and Reform Commission of the People's Republic of China, 2012).

et al. (2014) reported that the variation in the content of radionuclides $\left({ }^{226} \mathrm{Ra},{ }^{232} \mathrm{Th}\right.$, and $\left.{ }^{40} \mathrm{~K}\right)$ in soil, lignite fly ash, and crop produce depended on the types of soil and fly ash; mobilization of the radionuclides from soil/fly ash to the plant, and interactions between radionuclides and soil, etc. The content of the radionuclides in the soil, lignite fly ash, and crop produce was within the permissible limits. From the various reports, it can be concluded that, drawing direct comparisons between results in various reports is challenging, because of the varying methodologies, sample sizes, material properties, and experimental goals.

\section{Comprehensive applications}

Recycling coal fly ash can be a good alternative to disposal, and could achieve significant economic and environmental benefits as well. The global average utilization rate of fly ash is estimated to be nearly $25 \%$ (Bhattacharjee and Kandpal, 2002; Wang, 2008). Current utilization rates have been estimated at 50\% for the US, over $90 \%$ for the EU and $60 \%$ for India. For China, this rate has been increasing annually but has remained around $67 \%$ in recent years. It is expected to reach $70 \%$ by 2015 (see Fig. 3). However, there is a contradiction in the reported utilization rate in China; Greenpeace reported that the practical utilization rate is only $30 \%$ (Greenpeace, 2010). Whatever the exact figure, it is clear that a significant proportion of coal fly ash will be left untreated and that there is an urgent need for developing new recycling methods for it. Some current application fly ash is illustrated in Fig. 5 and described in the following sections.

\subsection{Soil amelioration}

Although limes and dolomite are commonly used to ameliorate soil acidity, they are not economic and environmentally friendly, and take a longer time to substantially improve the soil structure and physical properties. The physicochemical properties of coal fly ash including silt and clay-sized particles, low bulk density, higher water-holding capacity, favorable $\mathrm{pH}$, and source of essential plant nutrients, etc., make it a potential amendment for soils (Ram et al., 2006, 2007b; Pandey and Singh, 2010). In addition, use of fly ash instead of lime can reduce $\mathrm{CO}_{2}$ emission (during calcite calcination to produce lime), and thus reduce global warming. Coal fly ash, being mostly alkaline (depending on the coal source and operating condition of the plant), can be used for buffering the soil $\mathrm{pH}$. Alkaline fly ash was found chemically equivalent to approximately $20 \%$ reagent grade $\mathrm{CaCO}_{3}$ in increasing soil $\mathrm{pH}$. The soil $\mathrm{pH}$ changes are mainly dependent on the $\mathrm{pH}$ of fly ash and soil, the buffering capacity of soil, and the fly ash neutralizing capacity (Moliner and Street, 1982). Class C fly ash (generally having $\geq 15 \%$ $\mathrm{CaO}$ ) has been shown to have the ability to raise $\mathrm{pH}$ and hence has been applied at excessively high rates. Most Class $\mathrm{F}$ ashes with low $\mathrm{CaO}$ content $(<15 \%)$, on the other hand, have limited potential to ameliorate soil acidity. Manoharan et al. (2010) performed two applications of acidic (pH 3.28 and 3.96) and alkaline (pH 9.04 and 10.77) Class F ashes to acidic sandy clay and clay loam soils. The results showed that their efficiency in ameliorating soil acidity was relatively low, except for ash with a relatively high calcium carbonate equivalent. This alkaline ash raised the soil pH by 2 and 2.3 units with additions at 36 and 108 tonnes/ha, respectively. The amelioration of soil pH by fly ash has a tremendous role in bringing vast tracts of soils, including non-productive lands, waste lands, mine spoils, etc. (Ram and Masto, 2010; Masto et al., 2014).

Fly ash also contains some useful nutrients, such as P, S, K, Ca, Mg, Cu, $\mathrm{Mn}$ and Zn, which are beneficial for the plant growth. Researchers have found other beneficial effects: improving the soil texture, aeration, percolation, and water retention in the treated zone; reducing soil bulk density and the consumption of other soil amelioration agents; serving as an insecticide owing to the presence of abrasive silica in fly ash; and decreasing the mobility and availability of metals in the soil due to alkaline nature of fly ash (Ram et al., 2006, 2007b; Basu et al., 2009; Pandey and Singh, 2010; Ram and Masto, 2010, 2014; Shaheen et al., 2014). Lee et al. (2006) evaluated the rice productivity in silt loam and loamy sandy soils with added alkaline fly ash. It was found that the ash slightly increased the soil $\mathrm{pH}$ and $\mathrm{Si}, \mathrm{P}$, and $\mathrm{K}$ uptake by the rice plants, but did not result in an excessive uptake of heavy metals in the submerged paddy soil. Fly ash application improves the physical, chemical and biological qualities of soils to which it is applied. However, in fly ash most elements are associated with mineral matter. Thus, harmful effects such as the low availability of some nutrient elements have been reported. Other undesirable effects include excess salinity 

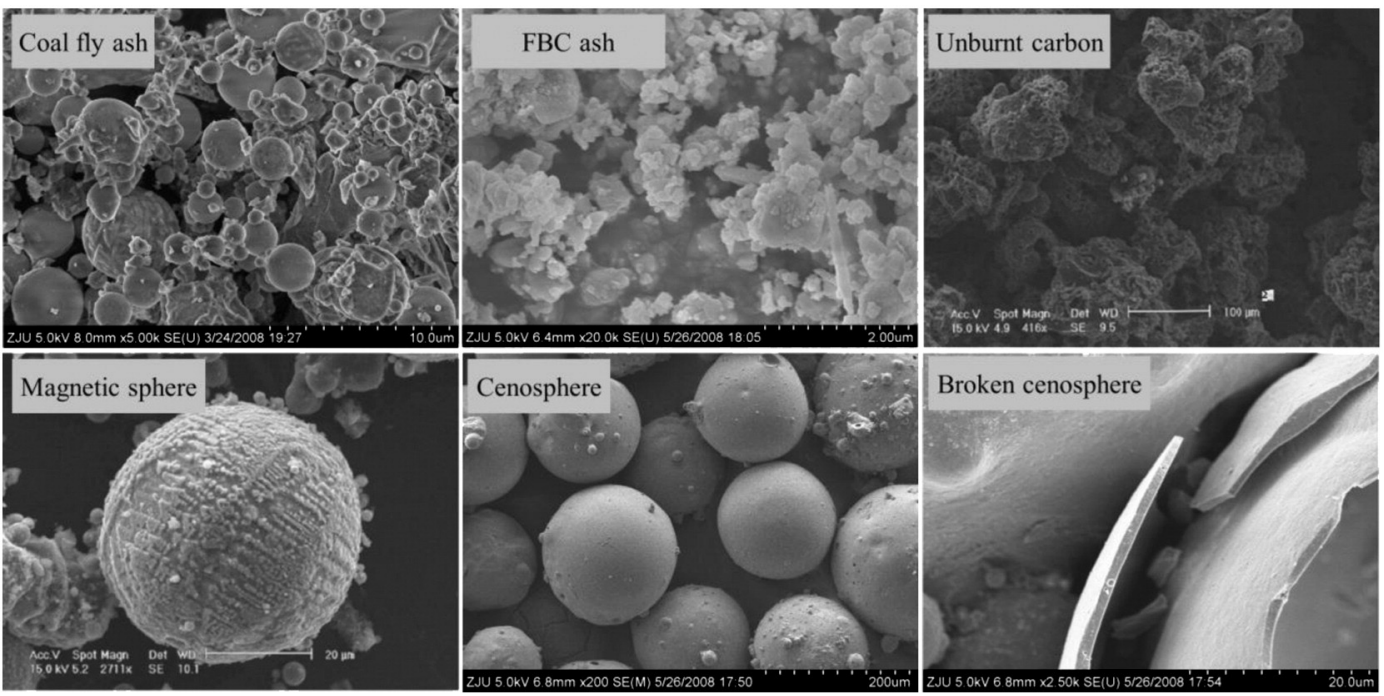

Fig. 4. SEM images of coal fly ash (Blissett and Rowson, 2011, 2012).

from fly ash to a soil-plant-human system, potential toxic side effects from heavy metals and a slow degradation rate of fly ash in soils (Matsi and Keramidas, 1999; Pandey et al., 2009; Bhattacharya et al., 2012). Manoharan et al. (2010) reported that the high salt content of Class F ash may limit its application as a liming material. Reductions in plant growth and yield were probably due to interactive effects of salinity and other elemental toxicity. Douay et al. (2002) tested the effect of fly ash integration on the bioavailability of toxic elements in calcium carbonate rich soils but noticed a reduced emergence of seedlings and delayed growth compared to the control soil. They explained these effects by a rise in $\mathrm{pH}$ and a poor integration of ashes with the soil.

Fly ash is devoid of humus and $\mathrm{N}$, attributable to the oxidation of $\mathrm{C}$ and $\mathrm{N}$ during coal combustion. The deficient $\mathrm{C}$ and $\mathrm{N}$ have to be amended along with fly ash application to soils, by which will support to supply $\mathrm{C}$ and $\mathrm{N}$, in addition to enhancing the efficiency of fly ash. A considerable amount of research has been carried out to blend fly ash with varieties of organic and inorganic materials, like lime, gypsum, red mud, farmyard manure, sewage sludge, composts, vermicompost, etc. The use of fly ash as an agricultural amendment can be enhanced by blending it with potentially acid-forming organic by-products such as sewage sludge, poultry and animal manure (Adriano et al., 1980; Haynes, 2009; Belyaeva and Haynes, 2012). There are also studies on the reclamation of fly ash dumps using plant species (Kumari et al., 2013; Pandey, 2013). Co-application of fly ash with these materials has more advantages: enhancing nutrient availability, decreasing bioavailability of toxic metals, buffering soil pH, enhancing soil organic matter content, indirectly stimulating microbial activity, overall improving soil health and increasing crop yield (see Fig. 6). Among the various amendments, the farm manure and sewage sludge are found to be more effective. However, it is better to seek the locally available fitting materials for exploiting the benefits from their synergistic interaction.

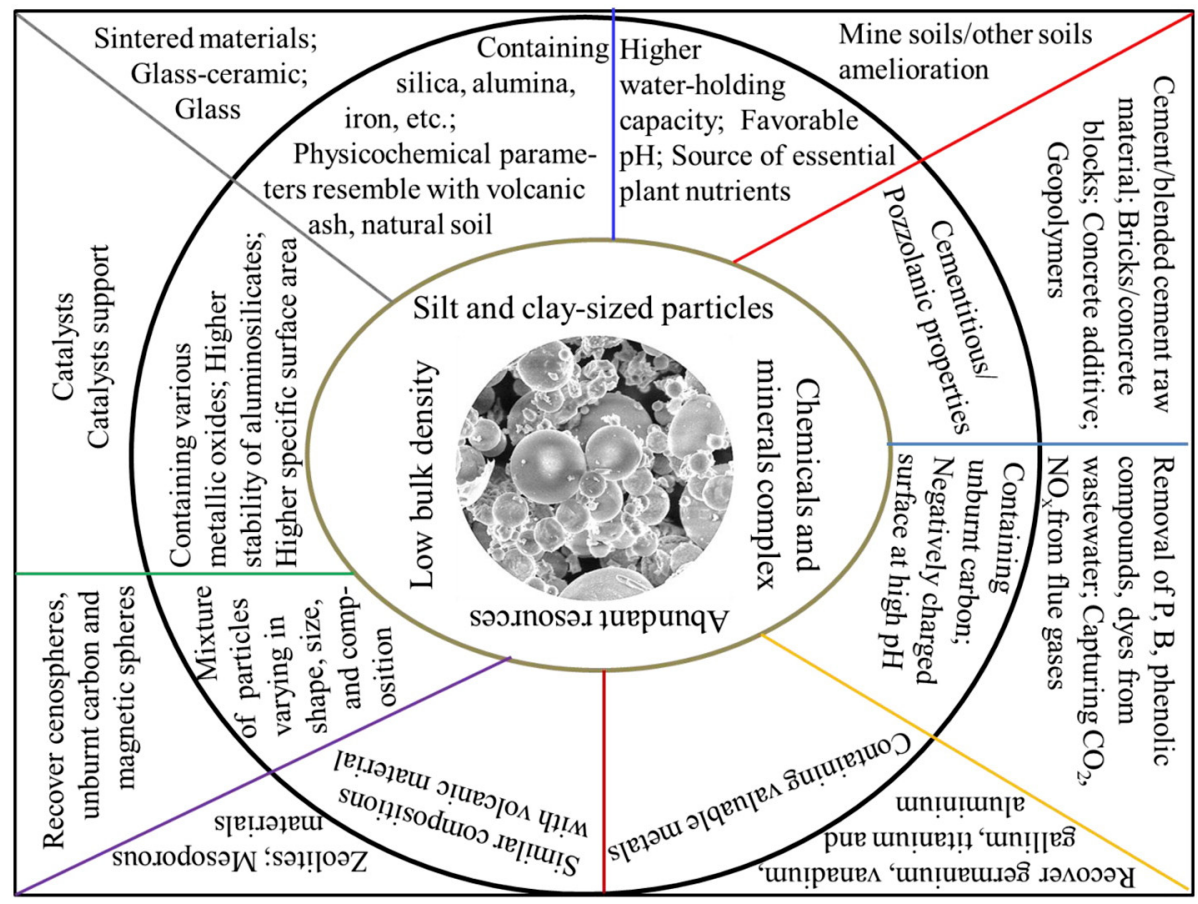

Fig. 5. Various applications of coal fly ash. 


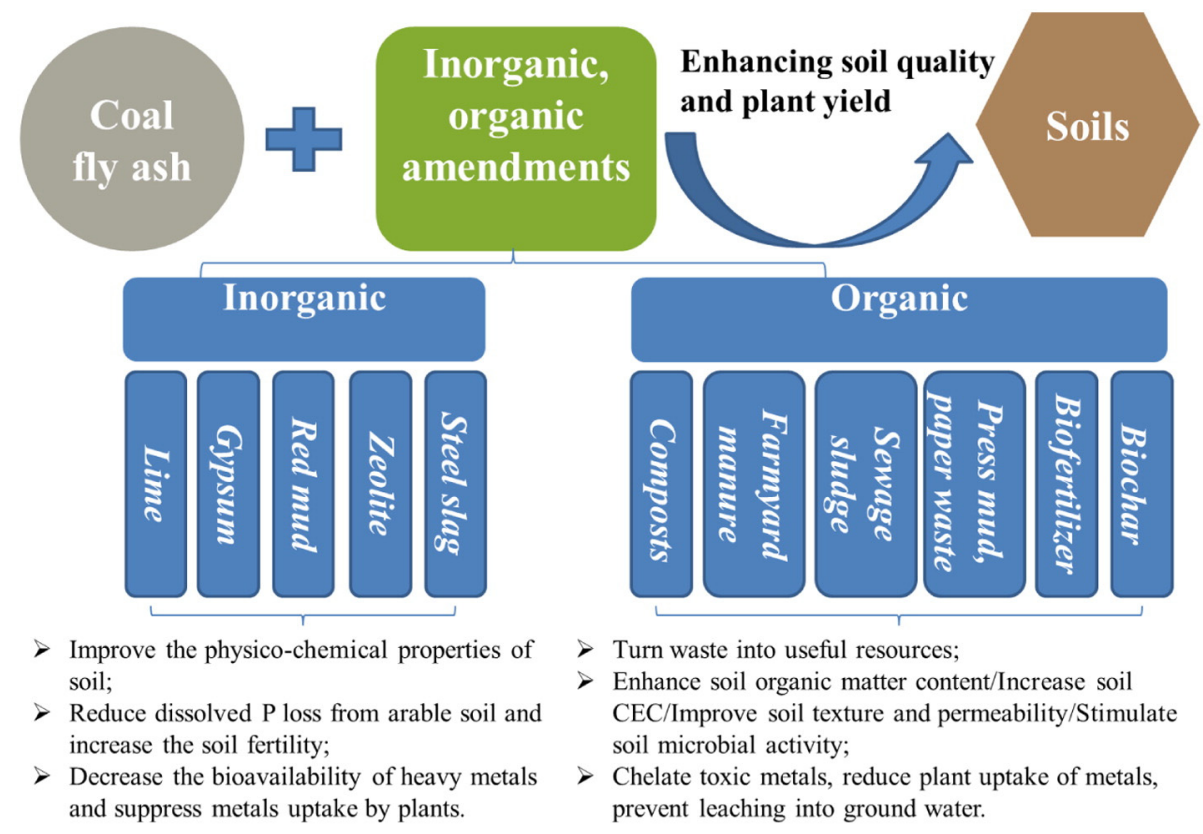

Fig. 6. The specific benefits of co-application fly ash with other amendments.

\subsection{Construction industry}

Fly ash has predominantly been used as a substitute for material in the construction industry, especially either as a raw material or as an additive in the cement industry. Fly ash can be referred to as either cementitious or pozzolanic depending on the $\mathrm{CaO}$ content. High calcium or Class C fly ash has considerable cementitious properties in addition to pozzolanic properties (ASTM, 2008), whereas Class F fly ash has mainly pozzolanic properties. The silica in fly ash reacts with calcium hydroxide released by the hydration of calcium oxide to produce calcium silicate hydrate (Nonavinakere and Reed, 1995). The pozzolanic properties make it useful for cement replacement in concrete and other building applications (González et al., 2009). Inclusion of fly ash in the binder improves the workability and reduces the bleeding of freshly mixed concrete. Partial cement replacement by Class F fly ash reduces the heat of hydration and thus the risk of cracking in concrete in its early stage (Sarker and McKenzie, 2009). Fly ash can improve the long-term durability properties of concrete by reducing the ingress of aggressive agents such a chloride ions (Nath and Sarker, 2011). Hardened fly ash concrete, when properly designed, shows increased strength together with a lower permeability (Taylor, 1997; Maroto-Valer et al., 2001a). In addition, partial replacement of cement with fly ash could reduce production costs. In general, the additive amount of fly ash for concrete ranges from 15 to $35 \mathrm{wt} . \%$ and can be up to $70 \mathrm{wt} . \%$ for concrete in constructions like pavement, walls and parking lots; and even as much as $80 \mathrm{wt} . \%$ in autoclaved aerated concrete (Dilmore and Neufeld, 2001). In China, approximately 41 and 19\% of the total ash were applied in cement and concrete manufacture in 2011. In India, approximately $45.5 \%$ of the ash produced was utilized by the cement and concrete industry. McCarthy and Dhir (2005) examined the use of high levels of low-lime fly ash as a cement component in concrete. The results indicated that fly ash levels of up to 45 wt.\% could be combined with portland cement to produce a range of practical concrete design strengths, although the early strength was reduced to some extent.

In the last decade, fly-ash-based geopolymer has emerged as a promising new cement alternative in the field of building and construction materials. Temuujin et al. (2010) prepared fly-ash-based geopolymer mortars with varying levels of sand aggregate. Their compressive strength and Young's modulus were $60 \mathrm{MPa}$ and 2.27 GPa respectively and these values did not change significantly with the addition of up to $50 \mathrm{wt} . \%$ sand aggregate. Joseph and Mathew (2012) studied the engineering properties of geopolymer concrete made from alkali-activated fly ash. This geopolymer concrete gave a higher value of Poisons ratio and modulus of elasticity compared to ordinary cement concrete. Research on fly-ash-based geopolymer concrete has shown its potential in various structural applications. It has been shown that fly-ash-based geopolymer concrete has similar strength and durability properties to those of traditional cement concrete. Fracture behavior and bond strength of heat-cured geopolymer concrete with reinforcing steel are found to be better than those of portland cement concrete (Sarker, 2011; Sarker et al., 2012). Fly-ashbased geopolymer concrete structural members can be designed by using the current design codes and standards used for portland cement concrete structures (Chang et al., 2007; Sarker, 2009). Recent research has shown that the need for heat curing of fly ash-based geopolymer concrete can be eliminated by the addition of small quantity of calcium bearing compound such as ground granulated blast furnace slag (Kikuchi, 1999; Sears, 2011). This development in the attempt of room-temperature curing of fly ash-based geopolymer concrete will widen its structural applications beyond precast concrete members.

A benefit has recently been demonstrated for recycling both the bottom ash and the FBC ash in pavement and roadway construction applications. The hydrated ash had a stiffness equal to or greater than that of limerock when used in both subgrade stabilization and base course applications. Besides the incorporation in concrete construction, fly ash is also used in geotechnical applications. Prashanth et al. (2001) examined the potential of pozzolanic fly ash as a hydraulic barrier in landfills. This study indicated that fly ash possessed low shrinkage and hence did not crack. Compacted fly ash underwent very little volume change. Cokca and Yilmaz (2004) reported that rubber and bentonite added to fly ash showed promise for the construction of liners.

From these reports, it can be concluded that fly ash can be effectively utilized in civil engineering projects. However, concerns have been raised about using fly ash as a cement substitute in concrete. Both the construction industry and the coal-fired power plants producing fly ash are affected by seasonal factors (Kikuchi, 1999), and their operations peak at different times: the construction industry needs most of its cement in the summer months when building conditions are optimum, whereas most of the ash is generated during the winter. In the summer, moreover, coal generators tend to be restricted to double 
shifting, causing the LOI content of the ash to be increased (Sears, 2011). This phenomenon may change the adsorption properties of ash in the air entrainment admixtures that are added in cement mixes. According to the ASTM C618 and EN 450-1 standards, an increase in LOI reduces the quality of fly ash. High carbon content can also lead to the discoloration of concrete and mixture segregation (Freeman et al., 1997).

\subsection{Ceramic industry}

Coal fly ash contains appreciable amounts of $\mathrm{SiO}_{2}, \mathrm{Al}_{2} \mathrm{O}_{3}, \mathrm{CaO}$ and $\mathrm{Fe}_{2} \mathrm{O}_{3}$, among other oxides. These oxides have often been considered a low-cost material for the ceramic industry. In addition, the fine powder form makes it suitable to be directly incorporated into ceramic pastes with almost no pretreatment (Erol et al., 2008a). Recent research has investigated the production of glass, glass-ceramic and sintered materials prepared from coal fly ash (see Fig. 7). The basis of manufacture is the temperature activation of the raw fly ash with variations in temperatures and co-reagents directing the final form of the glass or ceramic.

Due to their low or negative coefficient of thermal expansion (CTE), glass-ceramic materials based on $\mathrm{Li}_{2} \mathrm{O}-\mathrm{Al}_{2} \mathrm{O}_{3}-\mathrm{SiO}_{2}$ ternary system have important industrial applications. However, these materials are usually prepared by high grade reagents, causing the product to be very expensive. Recently, Kniess et al. (2007) prepared $\mathrm{Li}_{2} \mathrm{Al}_{2} \mathrm{Si}_{3} \mathrm{O}_{10}$ using coal bottom ash as raw materials. The determined CTE value was approximately $18 \%$ smaller than that for commercial lithium glass-ceramics. We also prepared $\mathrm{Li}_{2} \mathrm{Al}_{2} \mathrm{Si}_{3} \mathrm{O}_{10}$ using coal fly ash as a precursor. The obtained product was well crystallized and with small grain size (Yao et al., 2011a).

Cordierite has orthorhombic structure and occurs in three polymorphic forms. The high temperature form is well known as a-cordierite or indialite. As its low CTE, low dielectric constant and high refractoriness, cordierite ceramic is considered as a candidate for structural materials and finds applications as catalyst carriers for exhaust gas purification, heat exchangers for gas turbine engines, electronic packing materials, and refractory metal coatings, among other applications. Recently, the fly ash has been considered as a replacement for kaolinite in the manufacture of cordierite. He et al. (2005) prepared $\alpha$-cordierite using coal fly ash, alumina and magnesium carbonate. This mixture was milled with methyl cellulose and the blended components were then pressed into discs before sintering at temperatures of $900-1300{ }^{\circ} \mathrm{C}$ for $4 \mathrm{~h}$. The optimum conditions were determined as: $64-68 \mathrm{wt} . \%$ fly ash, $10 \%$ alumina, $22-26 \%$ magnesium carbonate, and sinter temperature of over $1200{ }^{\circ} \mathrm{C}$. Shao et al. (2004) prepared cordierite-based glass-ceramics from fly ash. The nucleation experiments were carried out at $840{ }^{\circ} \mathrm{C}$ for $2 \mathrm{~h}$ and crystallization experiments were performed at $1020{ }^{\circ} \mathrm{C}$ for $2 \mathrm{~h}$. We also prepared indialite using coal fly ash and magnesium carbonate as precursors (Yao et al., 2011b).

Ceramic tiles have been popular materials for interior and exterior decorations. Sokolar and Vodova (2011) used fly ash with kaolinic clay to manufacture dry pressed ceramic tiles. It is possible to use maximum 20 wt.\% of FBC ash in the fly ash-clay mixture. Kockal (2012) evaluated the effects of fly ash addition and sintering temperatures on the sintered properties of ceramic tile bodies. The results indicated that incorporating fly ash into the ceramic slurry produced a ceramic body with comparable properties as that of commercial ceramic materials.

In addition, Erol et al. (2008b) prepared glass, glass-ceramic and ceramic materials from fly ash with no additives. Microstructural, physical, chemical and mechanical properties of the produced glass-ceramic samples were better than those of glass and ceramic samples. Since the limited denitrification efficiency of trickling filters, suitable packing material should be utilized. Jing et al. (2012) prepared ceramic granules using fly ash, clay and diatomite, and employed them in trickling filters. The results showed that the prepared ceramic granules with high porosity and large pore area were appropriate packing materials for this biofilter. López-Badillo et al. (2013) reported that the use of fly ash greatly favored the kinetics of Celsian formation by a solid state reaction process, especially with $8 \mathrm{~h}$ of milling of the precursor mixture.

\subsection{Catalysis}

Metal and metal oxides are widely used as catalysts in various industrial applications. Fly ash mainly consists of various metal oxides with higher content of iron oxides and possesses higher thermal stability. Thus, utilization of fly ash in heterogeneous catalysis could provide a cost-effective and environmentally friendly method for recycling this waste (Wang, 2008). Besides, due to the higher stability of its principal component aluminosilicates, fly ash could also be employed as catalyst supports for various reactions. The catalytic role of activated fly ash for various reactions is well documented in reports. Fly-ash-supported $\mathrm{CaO}$ has been employed as a recyclable solid base catalyst for the Knoevenagel condensation reaction (Jain et al., 2010). Chakraborty et al. (2010) prepared a fly-ash-supported $\mathrm{CaO}$ catalyst for the transesterification of soybean oil. It exhibited high catalytic performance in converting soybean oil into fuel-grade biodiesel with a higher fatty acid methyl ester content (96.97\%). Khatri et al. (2010) synthesized a solid acid catalyst for benzylation reactions by loading sulfated zirconia on chemically activated fly ash. Saputra et al. (2012) employed
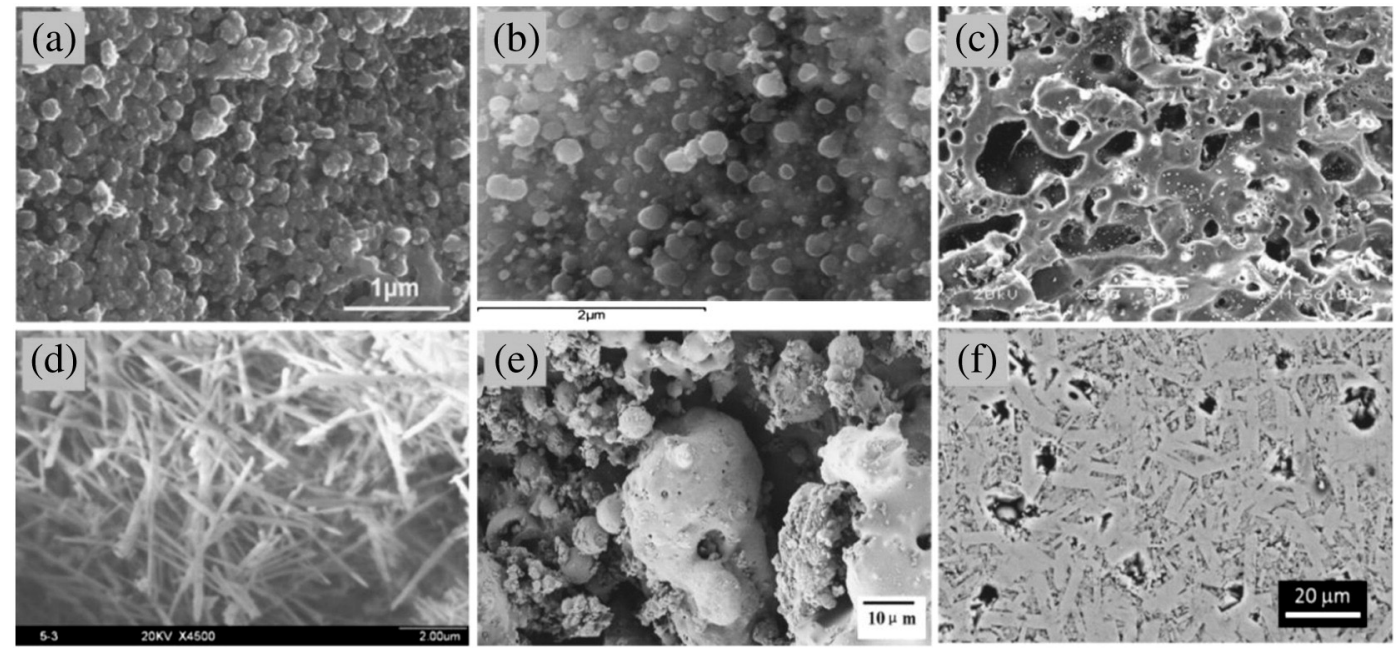

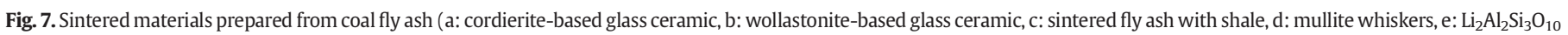
phase, f: $\mathrm{BaAl}_{2} \mathrm{Si}_{2} \mathrm{O}_{8}$ phase) (Peng et al., 2004; Wang and Liang, 2007; Mu et al., 2011; Tan, 2011; Yao et al., 2011a; López-Badillo et al., 2013). 
fly ash as a support for the synthesis of Co-oxide based catalyst. It could degrade phenol with the presence of oxone. Zhang et al. (2012) used nitric-acid-activated fly ash as a heterogeneous Fenton-like catalyst for p-nitrophenol removal from water. A removal rate of $98 \%$ was observed at the optimal conditions. Xuan et al. (2003) investigated the selective catalytic reduction (SCR) of $\mathrm{NO}$ with $\mathrm{NH}_{3}$ using a fly-ash catalyst. The results indicated that fly ash, after pre-treatment and loading with transition metal elements, can be reasonably used as an SCR catalyst support to remove NO from flue gas. Wang (2008) reported that fly ash can be used as an effective catalyst for reactions in gas-, liquid- and solidphases, such as gas phase oxidation of volatile organic compounds, aqueous phase oxidation of organics, solid plastic pyrolysis, and solvent free organic synthesis. Fly ash supported catalysts displayed good catalytic activities in deSOx, deNOx, $\mathrm{H}_{2}$ production, hydrocracking and hydrocarbon oxidation.

\subsection{Environmental protection}

Most fly ash is alkaline, and its surface is negatively charged at high $\mathrm{pH}$. Hence, it can be expected to remove metal ions from solutions by precipitation or electrostatic adsorption. Besides, it contains a certain volume of unburnt carbon, which has a high adsorption capacity. Fly ash has been investigated for its direct use as an adsorbent in both gaseous and aqueous applications. As early as 1984, fly ash was considered as a potential adsorbent to remove $\mathrm{Cu}^{2+}$ from industrial wastewaters (Panday et al., 1985). More recently the use of fly ash mixed with different chemical compositions has been evaluated for the removal of $\mathrm{B}, \mathrm{As}$, and a variety of different metal ions, such as $\mathrm{Cu}, \mathrm{Pb}, \mathrm{Zn}, \mathrm{Mn}, \mathrm{Cd}, \mathrm{Cr}$ and Ni. Polat et al. (2004) conducted a series of column and batch experiments to investigate the B removal from seawater and desalinated seawater using fly ash. A considerable amount ( $>90 \%$ ) of B could be removed. Cho et al. (2005) conducted batch experiments to evaluate heavy metal $(\mathrm{Zn}, \mathrm{Pb}, \mathrm{Cd}$ and $\mathrm{Cu})$ removal from aqueous solutions by fly ash. Most of the metal ions had a 95\% removal rate. Fly ash was also used for the removal of organic pollutants. Matheswaran and Karunanithi (2007) investigated the removal of Chrysoidine R from aqueous solution using fly ash as an adsorbent. Singh (2009) studied the adsorption of fly ash for the removal of metribuzin, metolachlor and atrazine from water. The amount of herbicides adsorbed increased with an increase in the fly ash amount. The maximum adsorption capacities of fly ash to metribuzin, metolachlor and atrazine were found to be $0.56,1.0$ and $3.33 \mathrm{mg} / \mathrm{g}$, respectively, by the Langmuir equation. Fly ash has also been found to be effective for the removal of polychlorinated biphenyls (Nollet et al., 2003).

Adsorption is considered to be one of the promising technologies for capturing $\mathrm{CO}_{2}, \mathrm{SO}_{2}$ and NOx from flue gases. Lu and Do (1991) used fly ash as an adsorbent for NOx removal. It was found that the unburnt carbon remaining in the fly ash particles contributed the main surface area to fly ash, and that the carbon can be activated to further improve the adsorption performance. Izquierdo and Rubio (2008) evaluated fly ash as an adsorbent for $\mathrm{SO}_{2}$ removal. A good removal capacity, which could be related to their textural properties, was shown by some samples. Sarmah et al. (2013) investigated the $\mathrm{CO}_{2}$ capturing capacity of amine fly-ash-based composites. A comparison of material cost and adsorption capacity showed that they were cheap and efficient for $\mathrm{CO}_{2}$ capture.

\subsection{Depth separation}

The recovery of cenospheres, unburnt carbon and magnetic spheres is one of the coal fly ash beneficiations, providing economic as well as environmental benefits. Cenospheres are formed during the molten state of ash and attain spherical shape to produce minimum surface tension. Their wall thickness is relatively thin, $<10 \%$ of the particle diameter. The density is typically less than $1 \mathrm{~g} / \mathrm{cm}^{3}$. The recovery of cenospheres was shown to be related to density by using water as the separating fluid. As Borm (1997) has stated, some materials in the fly ash are prone to dissolution upon contact with water. Some of these dissolved materials are toxic; thus, their accumulation in water needs to be controlled, which is a disadvantage of the wet-separation processes. In addition, the availability of land is a problem in densely populated countries, apart from the technical disadvantages related to the process. Air classification is one of the alternative techniques and a basic theoretical study comparing the efficiencies of dry separation with that of wet processes has been conducted (Hirajima et al., 2010). The estimated separation efficiency of the dry separation was as high as that of the wet separation and can be expected to be similar, at about $70 \%$. Petrus et al. (2011) investigated the separation efficiency of two types of air classifiers, a closed-type pneumatic separator and a micron separator. It was found that the latter has the potential to be applied in cenosphere recovery. In order to further confirm the applicability of this technique, a micron separator was deployed prior to the use of the wet-separation process. About $80 \%$ of the cenospheres were recovered, with an $87.8 \%$ reduction in the total mass of fly ash to be separated in the float and sink tank. Consequently, much less water was needed for the process of cenosphere recovery. The unique properties of cenospheres, namely hollow spheres and low density, make it amenable to a variety of applications. Kolay and Bhusal (2014) used distilled water to extract cenospheres lighter than $1.0 \mathrm{~g} / \mathrm{cm}^{3}$ and lithium metatungstate solution of density $1.5 \mathrm{~g} / \mathrm{cm}^{3}$ to extract cenospheres with density between 1.0 and $1.5 \mathrm{~g} / \mathrm{cm}^{3}$. The degree of rotation of the centrifuge and the duration of rotation are two important factors to influence the efficiency of this wet separation method of cenospheres. While the shell thickness of the cenospheres differed, no significant difference was observed in the particle sizes for the particles lighter and heavier than water.

Cenospheres have been used as fillers in cement to produce lightweight concrete (Blanco et al., 2000; Vassilev et al., 2004). Barbarea et al. (2003) studied the water uptake and loss in cenosphere-concrete composites, in an effort to understand their potential use as a fine aggregate in concrete. Recently, some researchers have studied the advantages of using cenospheres in composite materials by mixing it with metals and polymers to produce lightweight materials with higher strengths. Wasekar et al. (2012) studied the effects of the incorporation of cenospheres on the mechanical, thermal, and rheological properties of nylon 6 composites. Elongation was found to increase by $83 \%$ and impact strength by $44 \%$ at $2.5 \mathrm{phr}$ (parts per hundred) loading of cenospheres. Flexural strength increased by $25 \%$ at $10 \mathrm{phr}$ cenosphere content. Rohatgi et al. (2009) prepared polyester/cenosphere composites and studied their mechanical properties. The study showed that cenospheres can be used as a filler to enhance the mechanical properties and reduce the density of polyester matrix composites.

The recovered unburnt carbon from coal fly ash could serve as a fuel or a source of carbon-derived materials. Niewiadomski et al. (1999) used wet flotation to recover coke fines. The flotation concentrate from the air-sparged hydrocyclone contained 35\% coke by weight on a dry basis, with a coke recovery of 54\%. Yang (2000) used froth flotation to separate the carbonaceous portion from low-carbon fly ash. Carbon was separated as single grains in fly ash and the low-carbon fly ash was able to perform the role of pozzolanic activity index. In addition, by compounding the results of several iterations of flotation, the grade of unburnt carbon reached $75 \%$ and the heat value of the carbonaceous portion was $6000 \mathrm{kcal} / \mathrm{kg}$ for use as a fuel. Maroto-Valer et al. (2001b) recycled unburnt carbon using nitric acid, hydrochloric acid and hydrofluoric acid to dissolve fly ash. The grade of carbon was above $90 \%$ and could be used as adsorbents after being activated and as coke filler after being pelleted.

The removal of magnetic concentrate from fly ash is also a significant opportunity to create added value. It is conducted not only when the purpose of the reprocessing is to obtain Fe-rich products (Sripriya et al., 2003), but also in cases when iron is an undesirable ingredient, for instance in alumina production, or when there are limitations on its concentration in the final products (Prakash et al., 2001). The amount 
of magnetic material varies depending on the coal source and operating conditions of the coal boiler, but it can vary between 0.5 and $18 \%$ (Zyryanov et al., 2011). Magnetic separation is an effective approach for iron removal and it may be conducted in either a dry or a wet environment. The principle behind magnetic separation is straightforward; it relies on the fact that materials with different magnetic moments experience varying forces in the presence of magnetic field gradients. In this way, an externally applied magnetic field can lift out those materials with similar magnetic properties (Yavuz et al., 2009). Among the magnetic separation technologies, the use of wet magnetic separators holds advantages over that of dry magnetic separators. The combination of wet and dry magnetic separation appears to be another viable option offering the benefits of both technologies. Shoumkova (2011) used a wet low-intensity magnetic separation method to recover Fecontaining mineral from fly ash in Bulgaria. The concentrations of iron in the richest magnetic concentrates obtained from three fly ashes were 37.5, 16.8 and 26\%, respectively. Groppo and Honaker (2009) conducted a pilot-scale investigation into the potential for recovering the magnetic fraction from bottom ash. The process involved feeding the ash slurry through concentrating spirals which separated the ash into heavy and light fractions. From here the heavy ash fraction was fed to a continuous high gradient magnetic separator. The processing scheme was capable of producing magnetic material with an iron content of almost $75 \%$.

\subsection{Zeolite synthesis}

Synthesis of zeolites is gaining notice as one of the effective uses for coal fly ash, possibly due to the similar compositions of fly ash and some volcanic material, the precursor of natural zeolites. Since the pioneering work of Holler and Wirsching (1985), extensive studies have been undertaken and various types of zeolites prepared (see Fig. 8).

Zeolite synthesis is conventionally developed by hydrothermal crystallization under alkaline conditions (Querol et al., 2002). However, mullite and quartz in ash are considered to be inert and difficult to dissolve. In some cases, zeolite formation has been rather unsuccessful, taking into account that the resultant product is usually co-crystallized zeolites with original crystalline phases (e.g. quartz, mullite). The zeolitic aggregates form like an egg white, covering the central core of fly-ash particles. The zeolite yield and transformation efficiency is low (Shigemoto and Hayshi, 1993). Murayama et al. (2002) conducted a series of hydrothermal experiments for fly ash in various alkali solutions ( $\mathrm{NaOH}, \mathrm{KOH}, \mathrm{Na}_{2} \mathrm{CO}_{3}, \mathrm{NaOH} / \mathrm{KOH}$ and $\mathrm{Na}_{2} \mathrm{CO}_{3} / \mathrm{KOH}$ ) to clarify the mechanism of zeolite synthesis. It was found that the total reaction rate of zeolite synthesis was influenced by the $\mathrm{Na}^{+}$concentration in the alkali solution. When $\mathrm{Na}^{+}$and $\mathrm{K}^{+}$coexisted in the alkali solution, the crystallization rate decreased with an increase in $\mathrm{K}^{+}$concentration. Three steps, namely dissolution, condensation and crystallization, exist in an alkali hydrothermal reaction for zeolite synthesis. In our previous study (Yao et al., 2013), we investigated the hydrothermal reactions of fly ash in $\mathrm{LiOH} \cdot \mathrm{H}_{2} \mathrm{O}$ solutions, which acted as a strong activator and promoted the dissolution of inert phases. The contents of zeolites ABW phases increased at the expense of quartz and mullite with an increase of alkaline solution concentrations. Recently, the conventional method has been improved by using more sophisticated treatments, including an alkaline fusion followed by hydrothermal treatment (Rayalu et al., 2000), and the application of microwave-assisted zeolite synthesis (Querol et al., 1997). Shigemoto and Hayshi (1993) prepared Na-X zeolite from coal fly ash by fusion with sodium hydroxide prior to hydrothermal reaction. In our previous study (Yao et al., 2009b), the zeolite LiABW was synthesized by alkaline fusion followed by hydrothermal treatment in $\mathrm{LiOH} \cdot \mathrm{H}_{2} \mathrm{O}$ medium. Crystallinity of zeolite as high as $97.8 \%$ was attained under the following conditions: $\mathrm{LiOH} \cdot \mathrm{H}_{2} \mathrm{O}$ concentration, $3 \mathrm{M}$; hydrothermal temperature, $180^{\circ} \mathrm{C}$; and the corresponding aging time, $12 \mathrm{~h}$. Ansari et al. (2014) synthesized zeolites from fly ash via microwave heating methods. The pure zeolite $\mathrm{X}$ nanoparticles or a mixture of zeolite $\mathrm{X}$ and $\mathrm{A}$ can be synthesized using the microwave heating method by control of the crystallization time and temperature. A two-step process has also been developed (Hollman et al., 1999), which consists of an initial Si extraction from fly ash followed by adjusting the Si/Al molar ratio using $\mathrm{Al}$ from an external source. This method could significantly improve the zeolitization process and thus obtained high purity and crystalline zeolites. Wang et al. (2008) prepared pure-form zeolite A using the two-step process. This is, in
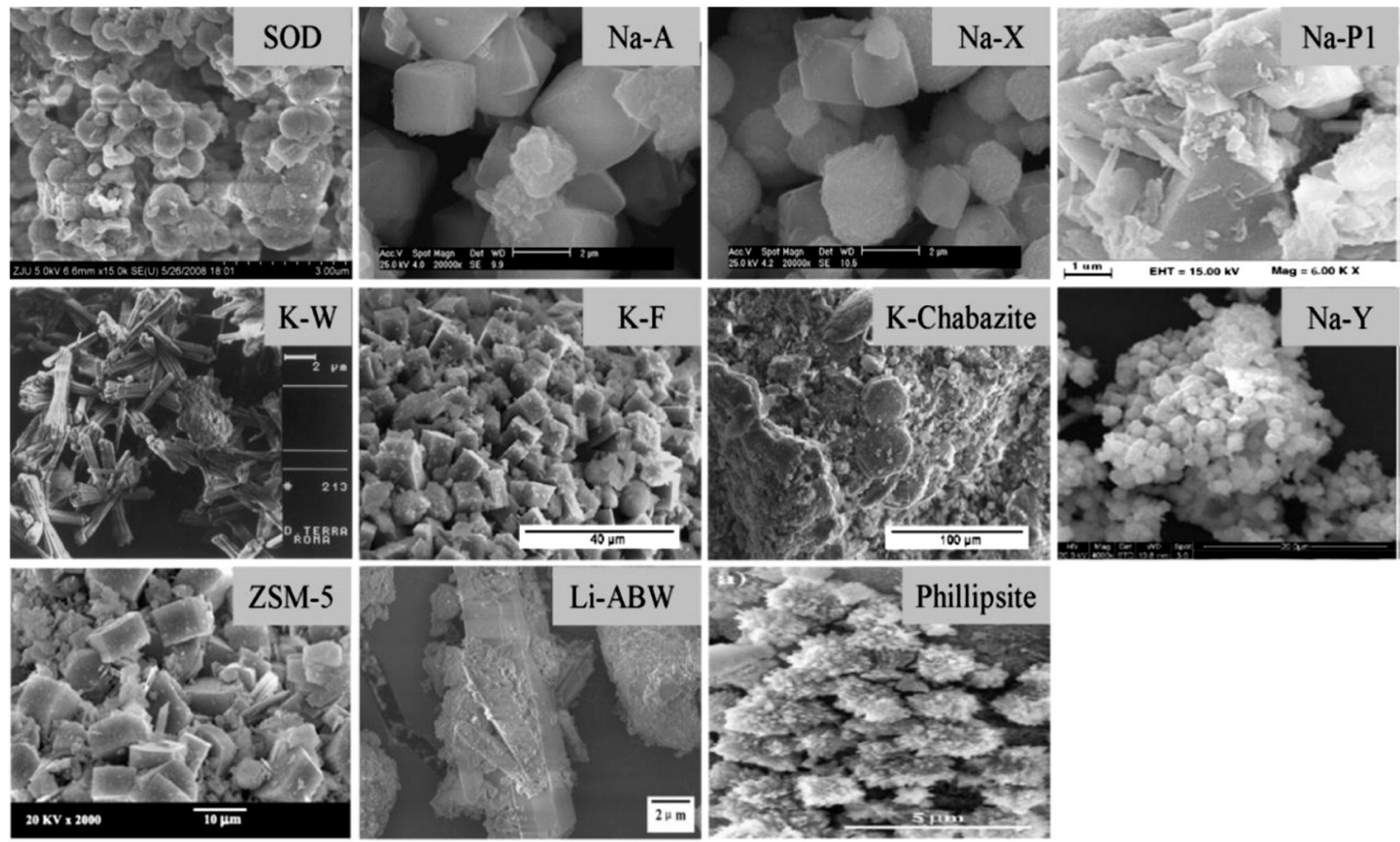

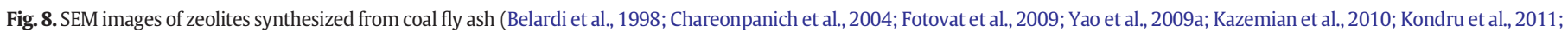
Yao et al., 2013). 
addition, a most unusual method of zeolite synthesis, using no water. Park et al. (2000a, 2000b) developed the technique of calcining fly ash $\left(<350{ }^{\circ} \mathrm{C}\right)$ with a mixture of a variety of salts and bases for a range of times not exceeding three days. The resultant zeolitic materials were composed mainly of sodalite and cancrinite. Although the need for water was eliminated, high temperatures and potentially long activation periods, in addition to a low selectivity for high CEC zeolites, somewhat limit the potential for this method.

The synthesized zeolites can be used in various engineering and agricultural applications for water purification, gas cleaning and soil amendment. Wang et al. (2009) prepared zeolites A and X from fly ash and evaluated the adsorption capacity of zeolites using $\mathrm{Cu}$ and $\mathrm{Zn}$ as target heavy metal ions. It was found that the adsorption capacity of zeolite A showed much higher value than that of zeolite X. The amount of $\mathrm{Cu}^{2+}$ adsorbed was $37.99 \mathrm{mg} / \mathrm{g}$; of $\mathrm{Zn}^{2+}, 29.68 \mathrm{mg} / \mathrm{g}$. Zhou et al. (2014) synthesized zeolite NaP1 and used it as adsorbents for volatile organic compounds. Babajide et al. (2012) prepared zeolite $\mathrm{Na}-\mathrm{X}$ and applied it as a solid base catalyst in the production of biodiesel. Li et al. (2014) prepared merlinoite and used it as a slow release Kfertilizer for plant growth. Liu et al. (2011) prepared Zeolite A and A + X mixtures and simulated the performance of the synthesized materials for $\mathrm{CO}_{2}$ capture. The results showed that both zeolites had performances superior to commercial zeolite X. Hence, zeolites prepared from waste fly ash can be used in commercial processes for $\mathrm{CO}_{2}$ capture and could be a cheap, viable means of producing large quantities of adsorbent (Wee, 2013).

\subsection{Valuable metal recovery}

Besides certain heavy elements, coal fly ash also contains valuable metals, including germanium $(\mathrm{Ge})$, gallium $(\mathrm{Ga})$, vanadium $(\mathrm{V})$, titanium (Ti) and aluminum ( $\mathrm{Al}$ ), which are extractable if an acceptable process can be developed. Ge is a valuable element used in the manufacture of light-emitting diodes, infrared optics, fiber optics, photovoltaic cells, and as a polymerization catalyst for polyethylene terephthalate. Sometimes $\mathrm{Ge}$ is concentrated in certain coals, where it is essentially joined to the organic matter. After coal is combusted, Ge is concentrated in combustion and gasification by-products, especially in fly ash, where the content is 10 times greater than in raw coal (Font et al., 2005). Therefore, one attractive source of Ge comes from the leaching of coal fly ash. Several studies have focused on Ge recovery from fly ash. The first step is the leaching of fly ash, followed by a process separating Ge from the other elements. The separation methods include precipitation with tannin, distillation of $\mathrm{GeCl}_{4}$, flotation, adsorption onto activated carbon, precipitation with cetyl trimethyl ammonium bromide, solvent extraction and adsorption onto chelating exchange resins (Jandova et al., 2002; Moskalyk, 2004; Hernandez-Exposito et al., 2006; Marco-Lozar et al., 2007; Fernández-Pereira and Arroyo Torralbo, 2009; Arroyo Torralvo et al., 2010). Arroyo Torralvo and FernándezPereira (2011) studied the Ge recovery from fly ash leachates using ion-exchange procedures. The procedure was based on Ge complexation with catechol in an aqueous solution followed by the retention of the Ge-catechol complex onto a conventional strongly basic anionic resin. The maximum amount of retained Ge was calculated to be $215.5 \mathrm{mg} / \mathrm{g}$ resin. The elution of the germanium complex was achieved with $\mathrm{HCl}$ in $50 \%$ ethanol solution. Recently, Arroyo Torralvo et al. (2011) studied the Ge recovery from fly ash leachates by solvent extraction procedures. The cost-effectiveness of the equipment was also estimated. They took data from a $5 \mathrm{~kg} / \mathrm{h}$ pilot plant, capable of recovering $1.3 \mathrm{~g} / \mathrm{h}$ of $\mathrm{GeO}_{2}$, to economically evaluate the potential of scaling this design up to process $200 \mathrm{~kg} / \mathrm{h}$ of fly ash. They estimated a capital cost of $€ 1.512$ million for the semi-industrial implantation without any solvent recovery unit included.

Ga is used widely in applications such as optoelectronics, telecommunications, photovoltaic, aerospace and many commercial and household items, such as alloys, computers, and DVDs. Although the crustal abundance of Ga ranges from 1 to 1.7 ppm, certain coals are enriched in $\mathrm{Ga}$, and when combusted the Ga content of the fly ash is enriched further with an enrichment factor of 6-10 times. Fang and Gesser (1996) studied the Ga recovery from coal fly ash, which included acid leaching, impurity removal, foam extraction of Ga and further purification. The two-stage leaching with $2 \mathrm{M}$ hydrochloric acid was sufficient to recover $95 \%$ of the $\mathrm{Ga}$. The processes used required the removal or modification of impurities, such as $\mathrm{SiO}_{3}$ ions, $\mathrm{Fe}^{3+}$, and $\mathrm{Ca}^{2+}$ in the leachate. Gutiérrez et al. (1997) also studied the Ga recovery by acid leaching and dual solvent extraction with commercial extractants Amberlite LA-2 and LIX 54 dissolved in kerosene. The acid leaching was carried out with $6 \mathrm{M}$ hydrochloric acid. The leaching liquor was first contacted with Amberlite LA-2 extracting the Ga and iron. The iron was then precipitated with sodium hydroxide, while Ga remained in solution. Ga was extracted selectively from the base solution with LIX 54; the resulting stripped solution contained $83 \%$ of the Ga present in the leaching liquor.

Coal fly ash is rich in alumium, making it a potential source of alumina. With the diminishing of bauxite resources as well as the increase in alumina demand, the profitable industrial utilization of coal fly ash in alumina recovery has attracted extensive attentions (Rayzman, 1997). The recovery of alumina from coal fly ash was pioneered by Grzymek (Hosterman et al., 1990) in Poland in the 1950s, based on the autodisintegration of sinter containing calcium aluminates and dicalcium silicate (Grzymek, 1976). The sinter was mixed with sodium carbonate and underwent a series of complicated chemical treatments including carbonization and water scrubbing to produce alumina and Portland cement. In 1953, a demonstration plant for recovering 10 thousand tonnes of alumina and producing 100 thousand tonnes of Portland cement was established in Poland. At the end of the 1970s, a second plant was established with the capability of producing 100 thousand tonnes of alumina and 1.2 million tonnes of cement. In the early 1970s, there was widespread concern about an impending producers' cartel of bauxite exporters, leading to higher prices. This concern led the US Bureau of Mines to undertake a major program of research into potential alternatives to bauxite. The processes studied included variations of existing leaching and sintering processes. Since the 1980s, more researches have been conducted and new recovery technologies developed as well. Recently, a number of processes for recovering alumina from coal fly ash have been reported, which can be grouped into three types: the sintering process, the acid leaching process and the HiChlor process (see Fig. 9). Padilla and Sohn (1985) studied the main variables in the sintering step and the kinetics of sodium aluminate formation during sintering. Alumina recovery of about $80 \%$ was obtained at optimal conditions. Wang et al. (2012) extracted aluminia by predesilication of fly ash, lime-soda sinter, water dissolution and carbonation processes. The desilication rate reached $40 \%$ and the extraction rate of alumina from the sinter reached as high as $91 \%$. Seeley et al. (1981) used the Calsinter process to recover alumina and the recovering rate reached more than 95\%. Shemi et al. (2012) employed a direct acid leach process to extract aluminia. The sulfuric acid leaching yielded an extraction efficiency of $23.5 \%$. Ji et al. (2007) calcined fly ash with soda at $900{ }^{\circ} \mathrm{C}$ to yield soluble aluminates. The sinter was then leached with sulfuric acid to produce a solution containing aluminum. The extraction efficiency reached as high as above $98 \%$. Mehrotra et al. (1982) investigated the high-temperature chlorination of fly ash using a gas-fluidized bed reactor. With carbon and carbon monoxide present as reducing agents, about $25 \%$ of the alumina in ash could be chlorinated in $2 \mathrm{~h}$ at temperatures above $900{ }^{\circ} \mathrm{C}$. We cannot detail records of all reports here. The history, involved reactions for each recovery technology has been presented in details in our previous work (Yao et al., 2014). The current plants performing alumina recovery from coal fly ash in China were also reported.

A number of recovery methods have been developed since the pioneering work of Grzymek. However, there are some drawbacks to all these methods and most reported work to date has been at the laboratory scale. The acid leaching processes can dissolve alumina and 


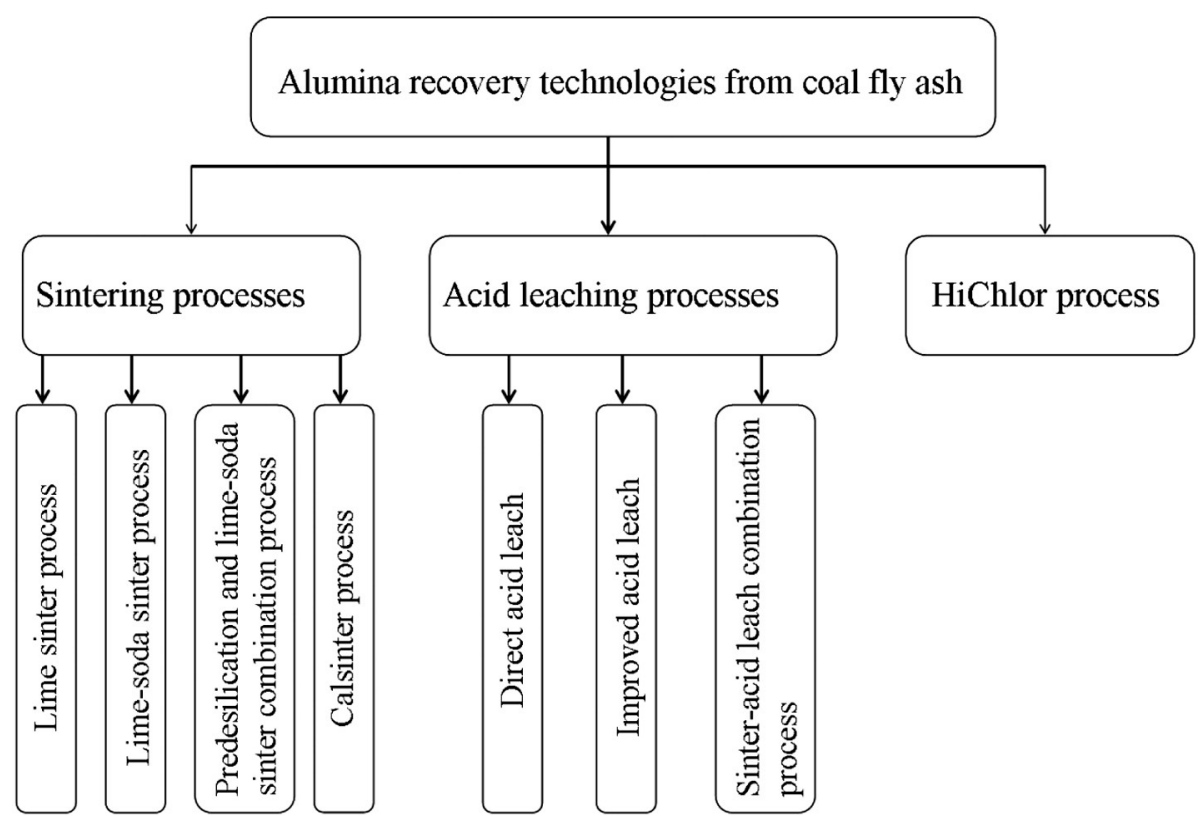

Fig. 9. Alumina recovery technologies from coal fly ash.

other metals with silicon-rich residue as by-products. However, it requires acid-resistant and air-tight processing equipment, such as that prepared from tantalum niobium alloy. In addition, alumina recovery and waste treatment can be quite complex. In the leaching process, a proportion of soluble impurities such as $\mathrm{Fe}$, Ti and $\mathrm{Mg}$ contained in the ash are introduced into the pregnant solution, necessitating posttreatment to purify the aluminum; another drawback of the acid process includes the low extraction rate and the necessary cost of environmental protection. Most sintering processes are not related to the simultaneous extraction of silica. In addition, a generous amount of calcium silicate residues are generated, but not utilized in an effective way except by manufacturing cement. It has been roughly calculated that 710 tonnes of calcium silicates will be generated in recovering 1 tonne of alumina product during the lime sinter process. Predesilication and the lime-soda sinter combination process offer the advantages of simultaneously extracting silica and reducing the solid residues to some extent. Other problems, however, such as filtration and the washing of desilicated liquor, are also confronted in the industrial application of these processes. The cost of each tonne of alumina can be hundreds to a thousand yuan higher than that of alumina produced from bauxite using the traditional Bayer process. While fewer residues are produced in the lime-soda sinter process, as compared with the lime sinter process, the energy cost is relatively high and the process is complex, problems that have restricted its large-scale application.

\section{Mode of utilization}

\subsection{China}

According to the annual report of China comprehensive resource utilization (2012) released by the National Development and Reform Commission (NDRC) of China, the coal fly ash generation and utilization were 540 and 367 million tonnes in 2011 respectively. The utilization rate reached $67.96 \%$, higher than that for the US (46.74\%) and India (55.79\%). Among the section of utilization, the top 3 were cement (41\%), brick and tiles (26\%) and concrete (19\%) (see Fig. 10). The remaining were road and embankments, agriculture and resource materials recovery (e.g. alumina, magnetite, carbon, cenospheres and gallium).

In China, the fly ash utilization has manifested the following features: (1) The recycling technology has innovated and utilization scale has enlarged significantly. The typical case is the alumina recovery from fly ash. Under a series of encouraged and preferential policies issued by the state and local government, the recovery of alumina is being aggressively undertaken in Inner Mongolia and Shanxi province, China. (2) The utilization of fly ash has been extended from conventional construction industry to depth separation and valuable metal recovery. (3) The total utilization has been increased although the utilization rate has remained $68 \%$ in recent years. The total utilization was 199 million tonnes in 2005 and significantly increased to 367 million tonnes in 2011. (4) The fly ash recycling companies could offer synergetic advantages by producing more materials or having different types of businesses. Thus, the waste recycling mode has evolved from "a single company" to "an eco-industrial park".

\subsection{India}

The generation of fly ash in India has increased from 68.88 million tonnes in 1996-97 to 163.56 million tonnes in 2012-13, of which only 100.37 million tonnes was utilized. India has achieved a tremendous increase in its utilization from $9.63 \%$ in $1996-97$ to $61.37 \%$ in $2012-13$. However, nearly $40 \%$ of the ash is still unused. The government of India launched several programs and established many agencies regarding better understanding of fly ash for its greater usage in different sectors. According to the CEA annual report on fly-ash generationutilization in 2011-12, the maximum utilization of fly ash to the extent of $44.76 \%$ has been in the cement sector, followed by the reclamation of low lying areas (16.71\%), mine filling (9.1\%), ash dyke raising (6.89\%), bricks and tiles (6.86\%), roads and embankments (6.51\%), and agriculture $(1.03 \%)$. Even after application in these sectors, only $55.79 \%$ of the total ash is utilized. Therefore, there exist a wide scope and an imperative need to increase the quantum of fly ash use in each sector. Especially there is a wide scope for brick and title, roads and embankments, mine filling, and soil amendment as the present utilization in these sector are relatively little.

The quantity of fly ash utilization in these applications may change in the future, thus an attempt is made to identify key applications. Loya and Rawani (2014) predicted the quantum of fly ash utilization to be contributed by key applications in coming future. Based on the annual time series data they identified pattern of growth using regression analysis and predicted the quantity of fly ash to be utilized in select applications. The maximum utilization of ash to the extent of $44.19 \%$ 

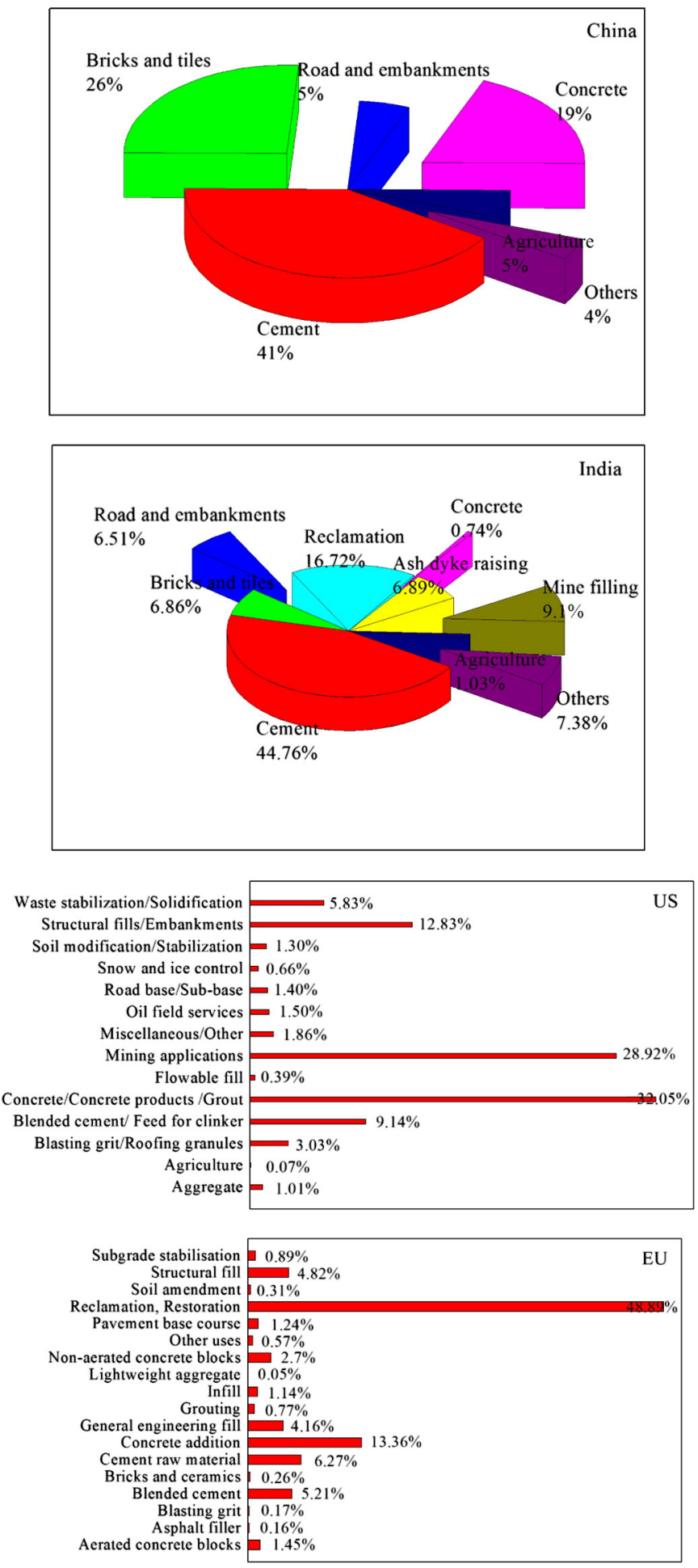

Fig. 10. Modes of fly ash utilization in China, India, US and EU.

predicted to be utilized is in cement and concrete sector in 2020-21. The second largest, $15.25 \%$ of ash to be utilized is in roads, embankments and ash dyke raising, followed by $12.49 \%$ in reclamation of low lying areas and land filling, $8.84 \%$ in mine filling, $7.61 \%$ in bricks, blocks and tiles, $2.47 \%$ in agriculture and $9.14 \%$ in others. Based on the future potentials, the top 5 application groups are: (i) cement and concrete, (ii) roads, embankments and ash dyke raising, (iii) reclamation of low lying areas and land filling, (iv) mine filling, and (v) bricks, blocks and tiles.

\subsection{US}

According to the ACAA, 77.76 million tonnes of fly ash, bottom ash, boiler slag and FBC ash was generated in 2012, out of which 39.03 million tonnes was utilized. The major modes of fly ash utilization along with the quantum in each mode are shown in Fig. 10. The maximum utilization of ash to the extent of $32.05 \%$ was contributed by concrete and grout section. The second largest, $28.92 \%$ of ash was mining applications, followed by $12.83 \%$ in structural fills and embankments, $9.14 \%$ in blended cement and feed for clinker, $5.83 \%$ in waste stabilization and solidification, and 3.03\% in blasting grit and roofing granules. The utilization of fly ash has been increasing in the past and to sustain this growth trend, the key application groups are identified as cement and concrete, agriculture, bricks and tiles, and reclamation.

\section{4. $E U$}

The European Coal Combustion Products Association (ECOBA) surveys and publishes data on the generation and utilization of CCPS in Europe. The ECOBA statistics reflect the typical combustion products such as fly ash, bottom ash, boiler slag and FBC ashes as well as the products from dry or wet flue gas desulphurization, especially spray dry absorption (SDA) product and FGD gypsum. With almost $68 \%$ of the total CCPs, fly ash is the most important combustion product. According to the annual production and utilization of CCPs released by the ECOBA, the generation and utilization of fly ash, bottom ash, boiler slag and FBC ash were calculated. As per the report, 37.58 million tonnes of ash was generated in 2010, out of which 35.23 million tonnes was utilized. The maximum utilization of ash to the extent of $48.89 \%$ was contributed by reclamation and restoration section. The second largest, $13.36 \%$ of total ash was used as concrete addition and is replacing a part of the cement in concrete, followed by $6.27 \%$ in cement raw material, $5.21 \%$ in blended cement, $4.82 \%$ in structure fill, and $4.16 \%$ in general engineering fill (see Fig. 10). To sustain this high utilization rate, the key application groups are identified as agriculture, bricks and tiles, resource recovery.

\section{Conclusions}

The generation of coal fly ash is anticipated to increase for many more years, as a result of the world's increasing reliance on coal-fired power generation. Understanding the generation, characterizations and hazards provides both a background and a basis for the alternative uses of fly ash. This review has attempted to investigate the production of fly ash at the global level and covers a wide range of applications to understand the status of fly ash utilization and thus develop alternative recycling technologies. The knowledge of the various ways to use fly ash, such as in soil amelioration, the construction industry, the ceramic industry and zeolite synthesis, is essential for better management of fly ash and the reduction of environmental pollution. There has been a steady progress in fly ash utilization in recent years and great reduction in fly ash consumption has been achieved. However, there are still some limitations for current applications (see Table 1).

Selectivity of $\mathrm{pH}$ and fly ash application dose is crucial to avoid harmful and undesirable effects on soil. The long-term effect of fly ash addition on field scale crop productivity and soil properties needs to be investigated. Fly ash reutilization is significant in the construction industry; however, some physical and engineering properties (e.g. chemical composition, LOI, moisture content and pozzolanic activity) are also required to meet the standards. The physical and chronological distances between fly ash production and cement manufacturing and other plants need to be taken into account. Generally, fly ash should be transported no more than $100 \mathrm{~km}$, and definitely not more than $200 \mathrm{~km}$; otherwise the production costs of recovery will be prohibitive. To promote the usage of fly ash, state and local governments should issue preferential policies that encourage its recycling, such as the preferential purchase of recycled fly ash products and reduction of the overall effective tax 
Table 1

The comparison of different applications of coal fly ash.

\begin{tabular}{|c|c|c|c|}
\hline Applications & Advantages & Disadvantages/limitations & Notice \\
\hline \multirow[t]{4}{*}{ Soil amelioration } & $\begin{array}{l}\text { 1. Being cost-effective and environmentally friendly } \\
\text { to substituting for lime and dolomite, although do } \\
\text { not replace chemical fertilizers or organic manures. }\end{array}$ & $\begin{array}{l}\text { 1. Lead to an increase in soil salinity for higher } \\
\text { concentration of total dissolved solids, total } \\
\text { hardness, cations and anions in fly ash } \\
\text { leachates. }\end{array}$ & $\begin{array}{l}\text { 1. Use weathered fly ash collected from ash } \\
\text { ponds than fresh ash. }\end{array}$ \\
\hline & 2. Buffer soil pH. & $\begin{array}{l}\text { 2. Pose a contamination risk to soil, plants and } \\
\text { ground water for comprising some toxic metals. }\end{array}$ & $\begin{array}{l}\text { 2. Add locally available amendments (farm } \\
\text { manure, sewage sludge, etc.) along with fly ash to } \\
\text { yield benefits from their synergistic interaction. }\end{array}$ \\
\hline & $\begin{array}{l}\text { 3. Increase the availability of plant nutrients except } \\
\text { organic } \mathrm{C} \text { and } \mathrm{N} \text {; reduce the dissolved } \mathrm{P} \text { in arable soil. }\end{array}$ & $\begin{array}{l}\text { 3. The application must be very specific depending } \\
\text { on the properties of ash and soil. }\end{array}$ & $\begin{array}{l}\text { 3. Reasonably control the addition amount of fly } \\
\text { ash. }\end{array}$ \\
\hline & $\begin{array}{l}\text { 4. Have beneficial effects on the physico-chemical } \\
\text { properties of soils, improve the microbiological } \\
\text { activity, and thus lead to higher plant biomass }\end{array}$ & $\begin{array}{l}\text { 4. Have potential phytotoxic effects when } \\
\text { relatively high rates of fly ash are applied. }\end{array}$ & $\begin{array}{l}\text { 4. Long term studies of the impact of fly ash on } \\
\text { soil health and crop quality. }\end{array}$ \\
\hline
\end{tabular}

Construction industry 1 . Partial replacement of cement with fly ash reduces 1 . The construction industry and the thermal the water demand; enhances the workability of concrete; and reduces the production costs of concrete and greenhouse gas emission during the cement production process.

2 . One of the best value-added uses and consumes 2 . Reduce compressive strength of concrete at a large quantity of ash.

3. There are no strict quality requirements for fly ash, especially used in flowable fill.

power plants producing ash are influenced by seasonal factors and their operations peak at different times. early ages, especially under cold weathe conditions or having more than $40 \%$ replacement of cement.

3. The cost involved in transportation of ash from production to utilization sites might limit the application.

4. Many quantities of unburnt carbon in fly ash inhibit air entraining performance and fluidity of flesh concrete.

Ceramic industry

1. The chemical composition and proper size range make it suitable to be directly incorporated into ceramic pastes with almost no pretreatmen 2. Partial substitution for kaolinite, feldspar and quartz, and thus efficiently saves limited natural resources.

Catalysis

Environmental protection

Depth separation

Zeolite synthesis

Valuable metal recovery
1. Employed as catalyst or catalyst supports for various reactions, providing a cost-effective and environmentally friendly way of recycling this waste, significantly reducing its environmental effects. 2. One of the best value-added uses, although consumes a relatively small quantity of ash.

1. Low-cost potential adsorbents that can be directly used in both gaseous and aqueous applications

2. Sorbents for the flue gas desulphurization process fit well with the IE ethos because of lying in close proximity to the ash generation.

1. Increase potential industrial synergy opportunities.

2. The recovery of cenospheres, unburnt carbon and magnetic spheres provides economic as well as environmental benefits.

1. Potential adsorbents used in various engineering and agricultural applications for water purification, gas cleaning and soil amendment.

2. One of the best value-added uses, although consumes a relatively small quantity of ash.

1. Increase potential industrial synergy opportunities.

2. Achieve significant economic and environmental benefits.
1. The iron oxides in fly ash have a negative

effect on the thermal expansion coefficient of product.

2. The fly ash-clay body showed a high

shrinkage after firing.

3. The firing shrinkage is compensated by the addition of FBC ash at the expense of increasing porosity of the body and sulphur dioxide content in flue gases.

4. Higher ash content leads to deformations and defects in the tiles because of extreme bloating. 1. The fly ash catalysts have not been applied in industrial practice.

2. Fly ash contains some trace elements, such as $\mathrm{Hg}$, which may be released during fly ash utilization and causes secondary pollution. 1. Fly ash adsorbents have a limited adsorption capacity.

2. The properties of fly ash are extremely variable and the adsorption capacity varies greatly among ashes.

1. Common wet separation processes require vast lands, large amounts of water and flotation reagents and easily result in second pollution.

2. The efficiency and economic are the major

limiting factors for various separations.

1. The resultant product is usually co-crystallized zeolites with original crystalline phases (e.g. quartz, mullite), especially for conventional hydrothermal process.

2. The efficiency and economic are the major limiting factors.

1. There are some drawbacks to the alumina recovery methods and most reported work to date has been at the laboratory scale.

2. The efficiency and economic are the major limiting factors.
1. Select the right quality fly ash to enhance the cement rather than be detrimental to the final concrete mix.

2. Increase the addition amount of fly ash at the premise of meeting the projects' demand.

3. The unburned carbon in fly ash should be less than $~ 3 \%$. It could be removed by dry or wet processes like electrostatic separation, gravitational separation, or froth flotation.

1. Reduce the iron oxide content. It could be removed by acid pretreatment or magnetic separation.

2. The ceramic body composition could be varied and the heating process could be adjusted to overcome these negative characteristics.

1. More research is required to investigate the performance of long-term stability of the catalysts.

2. The reaction mechanism and kinetics are important in applying the fly ash catalyst in a large scale industrial application.

1. Select the right quality fly ash and pretreat it to enhance the adsorption capacity.

2. The regeneration and disposal of adsorbents is needed to avoid second pollution.

1. The performance of depth separation should take into account of the ash discharge method, the properties of ash, the available land, the fly ash final product, etc.

1. The regeneration and disposal of adsorbents is needed to avoid second pollution.

2. Improve the preparation process and attempt to produce zeolites with higher adsorption capacity. 1. Economies of scale can be realized in alumina recovery.

2. The distance between fly ash sources and recycling sites needs to be taken into account. 3. Simultaneously recover more valuable materials, such as unburnt carbon, cenospheres, alumina, and gallium. 
rate for the recycling companies. The recycling capacity is relatively small in the ceramic industry, catalysis and zeolite synthesis. Fly ash has great potential for use in the treatment of wastewater and flue gas, but this potential is limited by the variability in the chemical composition of fly ash and by the large volumes that might be required. To improve the removal efficiencies and adsorption capacities, chemical modifications of fly ash are required. Functional ceramic materials and zeolites need to be developed to evaluate the added values of fly ash products. Depth separation, including the recovery of cenospheres, unburnt carbon and magnetic spheres, can be beneficial and facilitate the utilization of the mineral content for cement production and zeolite synthesis. It is worth noting that depth separation is usually the pretreatment of fly ash utilization and its conduction depends on the fly ash discharge method and the standards of the fly-ash final product. Recovery of valuable metals can be profitable; however, this process is complicated and should be combined with other uses, such as recovering aluminum and silicon. The treatment of residues should be also taken into account. To achieve utilization trend higher than the existing trends, the following two points may be considered. First, the growing trend of identified as key applications such as cement and concrete, mine reclamation, bricks and tiles, and road and embankments must be retained. Second, in addition to the first, underutilized large potential applications should be explored. The key underutilized application groups identified are: agriculture, waste stabilization, flowable fill, ceramic, and geopolymers. Actualizing the latent potential of underutilized application groups can assist in achieving additional utilization. However doing so may require an investigation on why these applications remain underutilized, what are the key barriers to adoption, and what changes should be done in strategy and action to overcome the identified barriers. These are important areas of investigations and may serve as agenda for future research.

\section{Future research and prospects}

Fly ash utilization is expected to increase potential industrial synergy opportunities because of the growth of various applications that can use the by-products of recycled fly ash. However, most reported methods are still in the early stages of commercialization. Further studies are needed to turn this research into commercial reality. The following recommendations can be made based on this research:

(1) Investigate the distribution of coal rich in valuable elements and its flow. Economies of scale can be realized in depth separation and valuable metal recovery. The annual alumina production is recommended to be no less than 500 thousand tonnes for each plant according to the practice of alumina recovery in China. The companies could offer synergetic advantages by producing more materials or having different types of businesses that include several follow-on products, such as "coal-electricity-fly ash-cenosphere/alumina/silica/gallium-cement" and "fly ashcenosphere/magnetic spheres/alumina/active calcium silicatealuminum alloy".

(2) Because the recent recycling technologies have their own disadvantages, there should be a greater emphasis on the development of new technologies. We can use combinations of processes, such as predesilication of fly ash and a lime-soda sinter process. It is also better to simultaneously recover more valuable materials, such as unburnt carbon, cenospheres, alumina, silica, gallium, and titanium. Additional work is needed to optimize the processing steps, particularly in the area of valuable elements purifying.

(3) Fly ash based geopolymer is emerging as a novel binder for applications in concrete technology by construction industries. In order to reach the full potential of the material, research needs to be continued on geopolymer binders, especially in the areas of its ambient curing and durability aspects.

(4) Exploring new amendments like agricultural and industrial wastes, biosolids, etc. for co-application with fly ash. Because of the variability in metal leaching data, there must be a careful assessment of the targeted fly ash before its application. Laboratory and field scale leaching studies involve fly ash and its blending with other organic and inorganic amendments. Field studies with different types of soil on the impact of fly ash on soil properties, clay mineralogy, microbial activity, diversity, and bio-indicators are needed as well.

\section{Acknowledgments}

This work was financially supported by Zhejiang Provincial Natural Science Foundation of China (grant no. LQ13B070005), National Natural Science Foundation of China (grant no. 41373121), Key Laboratory for Solid Waste Management and Environment Safety Open Fund (grant no. SWMES 2011-07), Scientific Research Fund of Zhejiang Provincial Education Department (grant no. Y201327380) and Chinese National 863 High Technology (grant no. 2007AA06Z128). We also would like to thank the anonymous referees for their helpful comments on this paper.

\section{References}

Adriano, D.C., Page, A.L., Elseewi, A.A., Chang, A., Straughan, I.A., 1980. Utilization and disposal of fly ash and other coal residues in terrestrial ecosystem: a review. J. Environ. Qual. 9, 333-344.

Ahmaruzzaman, M., 2010. A review on the utilization of fly ash. Prog. Energy Combust. Sci. 36, 327-363.

Ansari, M., Aroujalian, A., Raisi, A., Dabir, B., Fathizadeh, M., 2014. Preparation and characterization of nano-NaX zeolite by microwave assisted hydrothermal method. Adv. Powder Technol. 25, 722-727.

Arroyo Torralvo, F., Fernández-Pereira, C., 2011. Recovery of germanium from real fly ash leachates by ion-exchange extraction. Miner. Eng. 24, 35-41.

Arroyo Torralvo, F., Fernández-Pereira, C., Campanario, M.C., 2010. Recovery of germanium from aqueous solutions by ion-exchange extraction of its catechol complex. Ind Eng. Chem. Res. 49, 4817-4823.

Arroyo Torralvo, F., Fernández-Pereira, C., Bermejo Oroz, P., Olivares del Valle, J., 2011. Industrial equipment design for the recovery of germanium from coal fly ash leachates by solvent extraction. Proceedings of 2011 World of Coal Ash Conference, May 9-12, 2011, Denver, CO, USA

ASTM, 2008. Standard C618-08 Standard Specification for Coal Fly Ash and Raw or Calcined Natural Pozzolan for Use in Concrete. ASTM International, West Conshohocken, PA, USA.

Babajide, O., Musyoka, N., Petrik, L., Ameer, F., 2012. Novel zeolite Na-X synthesized from fly ash as a heterogeneous catalyst in biodiesel production. Catal. Today 190, 54-60.

Barbarea, N., Shuklab, A., Bosea, A., 2003. Uptake and loss of water in a cenosphere-concrete composite material. Cem. Concr. Res. 33, 1681-1686.

Basu, M., Pande, M., Bhadoria, P.B.S., Mahapatra, S.C., 2009. Potential fly-ash utilization in agriculture: a global review. Prog. Nat. Sci. 19, 1173-1186.

Belardi, G., Massimilla, S., Piga, L., 1998. Crystallization of K-L and K-W zeolites from fly-ash. Resour. Conserv. Recycl. 24, 167-181.

Belyaeva, O.N., Haynes, R.J., 2012. Comparison of the effects of conventional organic amendments and biochar on the chemical, physical and microbial properties of coal fly ash as a plant growth medium. Environ. Earth Sci. 66, 1987-1997.

Bhangare, R.C., Tiwari, M., Ajmal, P.Y., Sahu, S.K., Pandit, G.G., 2014. Distribution of natural radioactivity in coal and combustion residues of thermal power plants. J. Radioanal. Nucl. Chem. 300, 17-22.

Bhattacharjee, U., Kandpal, T.C., 2002. Potential of fly ash utilisation in India. Energy 27, 151-166.

Bhattacharya, S.S., Iftikar, W., Sahariah, B., Chattopadhyay, G.N., 2012. Vermicomposting converts fly ash to enrich soil fertility and sustain crop growth in red and lateritic soils. Resour. Conserv. Recycl. 65, 100-106.

Bhattacharyya, S., Donahoe, R.J., Patel, D., 2009. Experimental study of chemical treatment of coal fly ash to reduce the mobility of priority trace elements. Fuel 88, 1173-1184.

Blanco, F., Gareis, P., Materos, P., Ayala, J., 2000. Characteristics and properties of lightweight concrete manufactured with cenospheres. Cem. Concr. Res. 30, 1715-1722.

Blissett, R., Rowson, N., 2011. The processing of pulverised fuel ash. Proceedings of 15th Conference on Environment and Mineral Processing, June 8-10, 2011, Ostrava, Czech Republic.

Blissett, R.S., Rowson, N.A., 2012. A review of the multi-component utilisation of coal fly ash. Fuel 97, 1-23.

Borm, P.J.A., 1997. Toxicity and occupational health hazards of fly ash (CFA): a review of data and comparison to coal mine dust. Ann. Occup. Hyg. 41, 659-676.

Chakraborty, R., Bepari, S., Banerjee, A., 2010. Transesterification of soybean oil catalyzed by fly ash and egg shell derived solid catalysts. Chem. Eng. J. 165, 798-805

Chang, E.H., Sarker, P.K., Lloyd, N., Rangan, B.V., 2007. Shear behaviour of reinforced fly ash-based geopolymer concrete beams. Proceedings of the Concrete Institute of Australia 23rd Biennial Conference, October 18-20, 2007, Adelaide, Australia. 
Chareonpanich, M., Namto, T., Kongkachuichay, P., Limtrakul, J., 2004. Synthesis of ZSM-5 zeolite from lignite fly ash and rice husk ash. Fuel Process. Technol. 85, 1623-1634.

Cho, H., Oh, D., Kim, K., 2005. A study on removal characteristics of heavy metals from aqueous solution by fly ash. J. Hazard. Mater. B 127, 187-195.

Choi, S.K., Lee, S., Song, Y.K., Moon, H.S., 2002. Leaching characteristics of selected Korean fly ashes and its implication for the ground water composition near the ash disposal mound. Fuel 81, 1083-1090.

Cokca, E., Yilmaz, Z., 2004. Use of rubber and bentonite added fly ash as a liner material. Waste Manag. 24, 153-164.

Dilmore, R.M., Neufeld, R.D., 2001. Autoclaved aerated concrete produced with low-NOx burner/selective catalytic reduction fly ash. J. Energy Eng. 127, 37-50.

Douay, F., Dubourguier, H.C., Pruvot, C., Warin, A., 2002. Evaluation de lintérêt des cendres LFC pour le phytomanagement des sites contaminés par des métaux lourds. Rapport intermédiaire', Pôle de Compétences sur les Sites et Sédiments Pollués, Metaleurop. ISA, Lille 1, EDF, Surschiste, Apinor.

Erol, M., Küçükbayrak, S., Ersoy-Meriçboyu, A., 2008a. Characterization of sintered coal fly ashes. Fuel 87, 1334-1340

Erol, M., Küçükbayrak, S., Ersoy-Meriçboyu, A., 2008b. Comparison of the properties of glass, glass-ceramic and ceramic materials produced from coal fly ash. J. Hazard. Mater. 153, 418-425.

Fang, Z., Gesser, H.D., 1996. Recovery of gallium from coal fly ash. Hydrometallurgy 41, $187-200$.

Fernández-Pereira C, Arroyo Torralbo F. Method for the recovery of germanium in solution by means of complexing and use of ion-exchange resins. WO Patent WO2009106660, 03-09-2009.

Fernández-Turiel, J.L., de Carvalho, W., Cabañas, M., Querol, X., López-Soler, A., 1994. Mobility of heavy metals from coal fly ash. Environ. Geol. 23, 264-270.

Fisher, G.L., Prentice, B.A., Silberman, D., Ondov, J.M., Bierman, A.H., Ragaini, R.C., McFarland, A.R., 1978. Physical and morphological studies of size-classified coal fly ash. Environ. Sci. Technol. 12, 447-451.

Font, O., Querol, X., Lopez-Soler, A., Chimenos, J.M., Fernandez, A.I., Burgos, S., Garcia, Pena F., 2005. Ge extraction from gasification fly ash. Fuel 84, 1384-1392.

Fotovat, F., Kazemian, H., Kazemeini, M., 2009. Synthesis of Na-A and faujasitic zeolites from high silicon fly ash. Mater. Res. Bull. 44, 913-917.

Freeman, E., Gao, Y.M., Hurt, R., Suuberg, E., 1997. Interactions of carboncontaining fly ash with commercial air-entraining admixtures for concrete. Fuel 76, 761-765.

González, A., Navia, R., Moreno, N., 2009. Fly ashes from coal and petroleum coke combustion: current and innovative potential applications. Waste Manag. Res. 27 976-987.

Greenpeace, 2010. The True Cost of Coal-An Investigation Into Coal Ash in China. http:// www.greenpeace.org/usa/en/media-center/reports/The-True-Cost-of-Coal-CoalAsh-in-China/.

Groppo, J., Honaker, R., 2009. Economical recovery of fly ash-derived magnetics and evaluation for coal cleaning. Proceedings of 2009 World of Coal Ash (WOCA) Conference May 4-7, 2009, Lexington, KY, USA.

Grzymek, J., 1976. Prof. Grzymek's self-disintegration method for the complex manufacture of aluminum oxide and Portland cement. Proceedings of Sessions 105th AIME Annual Meeting, February 22-26, 1976, Las Vegas, NV, USA.

Gutiérrez, B., Pazos, C., Coca, J., 1997. Recovery of gallium from coal fly ash by a dual reactive extraction process. Waste Manag. Res. 15, 371-382.

Haynes, R.J., 2009. Reclamation and revegetation of fly ash disposal sites-challenges and research needs. J. Environ. Manag. 90, 43-53.

He, Y., Cheng, W.M., Cai, H.S., 2005. Characterization of $\alpha$-cordierite glass-ceramics from fly ash. J. Hazard. Mater. 120, 265-269.

Hernandez-Exposito, A., Chimenos, J.M., Fernandez, A.I., Font, O., Querol, X., Coca, P., Garcia, Pena F., 2006. Ion flotation of germanium from fly ash aqueous leachates. Chem. Eng. J. 118, 69-75.

Hirajima, T., Petrus, H.T.B.M., Oosako, Y., Nonaka, M., Sasaki, K., Ando, T., 2010. Recovery of cenospheres from fly ash using dry separation process: separation estimation and potential application. Int. J. Miner. Process. 95, 18-24.

Holler, H., Wirsching, U., 1985. Zeolite formation from fly ash. Forsch. Miner. 63, 21-43.

Hollman, G.G., Steenbruggen, G., Janssen-Jurkovičová, M., 1999. A two-step process for the synthesis of zeolites from coal fly ash. Fuel 78, 1225-1230.

Hosterman, J.W., Patterson, S.H., Good, E.E., 1990. World Nonbauxite Aluminum Resources Excluding Alunite. U.S. Government Printing Office, Washington.

Ilic, M., Cheeseman, C., Sollars, C., Knight, J., 2003. Mineralogy and microstructure of sintered lignite coal fly ash. Fuel 82, 331-336.

Izquierdo, M., Querol, X., 2012. Leaching behavior of elements from coal combustion fly ash: an overview. Int. J. Coal Geol. 94, 54-66

Izquierdo, M.T., Rubio, B., 2008. Carbon-enriched coal fly ash as a precursor of activated carbons for $\mathrm{SO}_{2}$ removal. J. Hazard. Mater. 155, 199-205.

Izquierdoa, M., Querol, X., 2012. Leaching behaviour of elements from coal combustion fly ash: an overview. Int. J. Coal Geol. 94, 54-66.

Jain, D., Khatri, C., Rani, A., 2010. Fly ash supported calcium oxide as recyclable solid base catalyst for Knoevenagel condensation reaction. Fuel Process. Technol. 91, $1015-1021$.

Jala, S., Goyal, D., 2006. Fly ash as a soil ameliorant for improving crop production-a review. Bioresour. Technol. 97, 1136-1147.

Jandova, J., Vu, H., Fecko, P., 2002. Recovery of germanium from Czech brown-coal fly ash. Proceedings of the 19th Annual International Pittsburgh Coal Conference, September 23-27, 2002, Pittsburgh, PA, USA.

Ji, H.M., Lu, H.X., Hao, X.G., Wu, P., 2007. High purity aluminia powders extracted from fly ash by the calcing-leaching process. J. Chin. Ceram. Soc. 35, 1657-1660.

Jing, Z.Q., Li, Y.Y., Cao, S.W., Liu, Y.Y., 2012. Performance of double-layer biofilter packed with coal fly ash ceramic granules in treating highly polluted river water. Bioresour. Technol. 120, 212-217.
Joseph, B., Mathew, G., 2012. Influence of aggregate content on the behavior of fly ash based geopolymer concrete. Sci. Iran. A 19, 1188-1194.

Kazemian, H., Naghdali, Z., Ghaffari Kashani, T., Farhadi, F., 2010. Conversion of high silicon fly ash to Na-P1 zeolite: alkaline fusion followed by hydrothermal crystallization. Adv. Powder Technol. 21, 279-283.

Khatri, C., Mishra, M.K., Rani, A., 2010. Synthesis and characterization of fly ash supported sulfated zirconia catalyst for benzylation reactions. Fuel Process. Technol. 91, $1288-1295$.

Kikuchi, R., 1999. Application of coal ash to environmental improvement: transformation into zeolite, potassium fertilizer, and FGD absorbent. Resour. Conserv. Recycl. 27, 333-346.

Kniess, C.T., De Lima, J.C., Prates, P.B., Kuhnen, N.C., Riella, H.G., 2007. Dilithium dialuminium trisilicate phase obtained using coal bottom ash. J. Non-Cryst. Solids 353, 4819-4822.

Kockal, N.U., 2012. Utilisation of different types of coal fly ash in the production of ceramic tiles. Bol. Soc. Esp. Ceram. Vidrio 51, 297-304.

Kolay, P.K., Bhusal, S., 2014. Recovery of hollow spherical particles with two different densities from coal fly ash and their characterization. Fuel 117, 118-124.

Kolbe, J.L. Lee, L.S., Jafvert, C.T., Murarka, I.P., 2011. Use of alkaline coal ash for reclamation of a former strip mine. Proceedings of 2011 World of Coal Ash (WOCA) Conference, May 9-12, 2011, Denver, CO, USA.

Kondru, A.K., Kumar, P., Teng, T.T., Chand, S., Wasewar, K.L., 2011. Synthesis and characterization of $\mathrm{Na}-\mathrm{Y}$ zeolite from coal fly ash and its effectiveness in removal of dye from aqueous solution by wet peroxide oxidation. Arch. Environ. Sci. 5, 46-54.

Kovler, K., 2012. Does the utilization of coal fly ash in concrete construction present a radiation hazard? Constr. Build. Mater. 29, 158-166.

Kumari, A., Pandey, V.C., Rai, U.N., 2013. Feasibility of fern Thelypteris dentata for revegetation of coal fly ash landfills. J. Geochem. Explor. 128, 147-152.

Lee, G.S., Han, G.Y., Kim, S.D., 1984. Coal combustion characteristics in a circulating fast fluidized bed. Korean J. Chem. Eng. 1, 71-76.

Lee, H., Ha, H.S., Lee, C.H., Lee, Y.B., Kim, P.J., 2006. Fly ash effect on improving soil properties and rice productivity in Korean paddy soils. Bioresour. Technol. 97, 1490-1497.

Li, J., Zhuang, X.G., Font, O., Moreno, N., Ramon Vallejo, V., Querol, X., Tobias, A., 2014. Synthesis of merlinoite from Chinese coal fly ashes and its potentialutilization as slow release K-fertilizer. J. Hazard. Mater. 265, 242-252.

Lior, N., 2010. Sustainable energy development: the present (2009) situation and possible paths to the future. Energy 35, 3976-3994.

Liu, L.Y., Singh, R., Xiao, P., Webley, P.A., Zhai, Y.C., 2011. Zeolite synthesis from waste fly ash and its application in $\mathrm{CO}_{2}$ capture from flue gas streams. Adsorption 17, 795-800.

López-Badillo, C.M., López-Cuevas, J., Gutiérrez-Chavarría, C.A., Rodríguez-Galicia, J.L., Pech-Canul, M.I., 2013. Synthesis and characterization of $\mathrm{BaAl}_{2} \mathrm{Si}_{2} \mathrm{O}_{8}$ using mechanically activated precursor mixtures containing coal fly ash. J. Eur. Ceram. Soc. 33, 3287-3300.

Loya, M.I.M., Rawani, A.M., 2014. A review: promising applications for utilization of fly ash. Int. J. Adv. Technol. Eng. Sci. 2, 143-149.

Lu, G.Q., Do, D.D., 1991. Adsorption properties of fly ash particles for NOx removal from flue gases. Fuel Process. Technol. 27, 95-107.

Manoharan, V., Yunusa, I.A.M., Loganathan, P., Lawrie, R., Skilbeck, C.G., Burchett, M.D., Murray, B.R., Eamus, D., 2010. Assessments of Class F fly ashes for amelioration of soil acidity and their influence on growth and uptake of Mo and Se by canola. Fuel 89, 3498-3504.

Marco-Lozar, J.P., Cazorla-Amorós, D., Linares-Solano, A., 2007. A new strategy for germanium adsorption on activated carbon by complex formation. Carbon 45 , 2519-2528.

Maroto-Valer, M., Taulbee, D., Hower, J., 2001a. Characterization of differing forms of unburned carbon present in fly ash separated by density gradient centrifugation. Fuel $80,795-800$

Maroto-Valer, M.M., Zhang, Y., Andrésen, J.M., Jones, A., Morrison, J.L., 2001b. Routes for the development of value added products from high carbon fly ashes. Prepr. Pap. Am. Chem. Soc. Div. Fuel Chem 46, pp. 316-317.

Masto, R.E., Sengupta, T., George, J., Ram, L.C., Sunar, K.K., Selvi, V.A., Sinha, A.K., 2014. The impact of fly ash amendment on soil carbon. Energy Sources Part A 36, 554-562.

Matheswaran, M., Karunanithi, T., 2007. Adsorption of Chrysoidine R by using fly ash in batch process. J. Hazard. Mater. 145, 154-161.

Mathur, A.K., Kumar, R., Mishra, M., Sengupta, D., Prasad, R., 2008. An investigation of radon exhalation rate and estimation of radiation doses in coal and fly ash samples. Appl. Radiat. Isot. 66, 401-406.

Matsi, T., Keramidas, V.Z., 1999. Fly ash application on two acid soils and its effect on soil salinity, pH, B, P and on ryegrass growth and composition. Environ. Pollut. 104, 107-112.

McCarthy, M.J., Dhir, R.K., 2005. Development of high volume fly ash cements for use in concrete construction. Fuel 84, 1423-1432.

Mehrotra, A.K., Behle, L.A., Raj Blshnol, P., Svrcek, W.Y., 1982. High-temperature chlorination of coal ash in a fluidized bed. 1. Recovery of aluminum. Ind. Eng. Chem. Process. Des. Dev. 21, 37-44

Moliner, A.M., Street, J.J., 1982. Effect of fly ash and lime on growth and composition of corn on acid sandy soils. Soil Crop Sci. Soc. Fla. Proc. 41, 217-220.

Moskalyk, R.R., 2004. Review of germanium processing worldwide. Miner. Eng. 17, 393-402.

Mu, S., Ma, B.G., Schutter, G.D., Li, X.G., Wang, Y.C., Jian, S.W., 2011. Effect of shale addition on properties of sintered coal fly ash. Constr. Build. Mater. 25, 617-622.

Murayama, N., Yamamoto, H., Shibata, J., 2002. Mechanism of zeolite synthesis from coal fly ash by alkali hydrothermal reaction. Int. J. Miner. Process. 64, 1-17.

Nath, P., Sarker, P., 2011. Effect of fly ash on the durability properties of high strength concrete. Procedia Eng. 14, 1149-1156. 
National Development and Reform Commission of the People's Republic of China, 2012 Annual Report on Comprehensive Utilization of Resources of China. http://www. gov.cn/gzdt/2013-04/08/content_2372577.htm.

Neupane, G., Donahoe, R.J., 2013. Leachability of elements in alkaline and acidic coal fly ash samples during batch and column leaching tests. Fuel 104, 758-770.

Niewiadomski, M., Hupka, J., Bokotko, R., Miller, J.D., 1999. Recovery of coke fines from fly ash by air sparged hydrocyclone flotation. Fuel 78, 161-168.

Nollet, H., Roels, M., Lutgen, P., Van der, M.P., Verstraete, W., 2003. Removal of PCBs from wastewater using fly ash. Chemosphere 53, 655-665.

Nonavinakere, S., Reed, B.E., 1995. Fly ash enhanced metal removal process. In: Sengupta, A.K. (Ed.), Hazardous and Industrial Wastes: Proceedings of the Twenty-seventh Mid-Atlantic Industrial Waste Conference. Technomart Publishing.

Nyale, S.M., Eze, C.P., Akinyeye, R.O., Gitari, W.M., Akinyemi, S.A., Fatoba, O.O., Petrik, L.F., 2014. The leaching behaviour and geochemical fractionation of trace elements in hydraulically disposed weathered coal fly ash. J. Environ. Sci. Health A 49, 233-242.

Padilla, R., Sohn, H.Y., 1985. Sintering kinetics and alumina yield in lime-soda sinter process for alumina from coal wastes. Metall. Mater. Trans. B 16, 385-395.

Panday, K.K., Prasad, G., Singh, V.N., 1985. Copper(II) removal from aqueous solutions by fly ash. Water Res. 19, 869-873.

Pandey, V.C., 2013. Suitability of Ricinus communis L. cultivation for phytoremediation of fly ash disposal sites. Ecol. Eng. 57, 336-341.

Pandey, V.C., Singh, N., 2010. Impact of fly ash incorporation in soil systems. Agric. Ecosyst. Environ. 136, 16-27.

Pandey, V.C., Abhilash, P.C., Singh, N., 2009. The Indian perspective of utilizing fly ash in phytoremediation, phytomanagement and biomass production. J. Environ. Manag. 90, 2943-2958.

Park, M., Choi, C.L., Lim, W.T., Kim, M.C., Choi, J., Heo, N.H., 2000a. Molten-salt method for the synthesis of zeolitic materials I. Zeolite formation in alkaline molten-salt system. Microporous Mesoporous Mater. 37, 81-89.

Park, M., Choi, C.L., Lim, W.T., Kim, M.C., Choi, J., Heo, N.H., 2000b. Molten-salt method for the synthesis of zeolitic materials: II. Characterization of zeolitic materials. Microporous Mesoporous Mater. 37, 91-98.

Patra, K.C., Rautray, T.R., Nayak, P., 2012. Analysis of grains grown on fly ash treated soils. Appl. Radiat. Isot. 70, 1797-1802.

Peng, F., Liang, K.M., Hu, A.M., Shao, H., 2004. Nano-crystal glass-ceramics obtained by crystallization of vitrified coal fly ash. Fuel 83, 1973-1977.

Petrus, H.T.B.M., Hirajima, T., Oosako, Y., Nonaka, M., Sasaki, K., Ando, T., 2011. Performance of dry-separation processes in the recovery of cenospheres from fly ash and their implementation in a recovery unit. Int. J. Miner. Process. 98, 15-23.

Polat, H., Vengosh, A., Pankratov, I., Polat, M., 2004. A new methodology for removal of boron from water by coal and fly ash. Desalination 164, 173-188.

Prakash, S., Mohanty, J.K., Dass, B., Venugopal, R., 2001. Characterisation and removal of iron from fly ash of talcher area, Orissa, India. Miner. Eng. 14, 123-126.

Prashanth, J.P., Sivapullaiah, P.V., Sridharan, A., 2001. Pozzolanic fly ash as hydraulic barrier in land fills. Eng. Geol. 60, 245-252.

Querol, X., Alastuey, A., Lopez-Soler, A., Plana, F., 1997. A fast method of recycling fly ash: microwave assisted zeolite synthesis. Environ. Sci. Technol. 31, 2527-2533.

Querol, X., Moreno, N., Umaña, J.C., Alastuey, A., Hernández, E., López-Soler, A., Plana, F., 2002. Synthesis of zeolite from coal fly ash: an overview. Int. J. Coal Geol. 50, 412-423.

Ram, L.C., Masto, R.E., 2010. An appraisal of the potential use of fly ash for reclaiming coal mine spoil. J. Environ. Manag. 91, 603-617.

Ram, L.C., Masto, R.E., 2014. Fly ash for soil amelioration: a review on the influence of ash blending with inorganic and organic amendments. Earth-Sci. Rev. 128, 52-74.

Ram, L.C., Srivastava, N.K., Tripathi, R.C., Jha, S.K., Sinha, A.K., Singh, G., Manoharan, V., 2006. Management of mine spoil for crop productivity with lignite fly ash and biological amendments. J. Environ. Manag. 79, 173-187.

Ram, L.C., Srivastava, N.K., Tripathi, R.C., Thakur, S.K., Sinha, A.K., Jha, S.K., Masto, R.E., Mitra, S., 2007a. Leaching behavior of lignite fly ash with shake and column tests. Environ. Geol. 51, 1119-1132.

Ram, L.C., Srivastava, N.K., Jha, S.K., Sinha, A.K., Masto, R.E., Selvi, V.A., 2007b. Management of lignite fly ash for improving soil fertility and crop productivity. Environ. Manag. 40, 438-452.

Rayalu, S., Meshram, S.U., Hasan, M.Z., 2000. Highly crystalline faujasitic zeolites from fly ash. J. Hazard. Mater. 77, 123-131.

Rayzman, V.L., 1997. Technology for chemical-metallurgical coal ash utilization. Energy Fuel 11, 761-773.

Rohatgi, P.K., Matsunaga, T., Gupta, N., 2009. Compressive and ultrasonic properties of polyester/fly ash composites. J. Mater. Sci. 44, 1485-1493.

Saikia, N., Kato, S., Kojima, T., 2006. Compositions and leaching behaviors of combustion residues. Fuel 85, 264-271.

Saputra, E., Muhammad, S., Sun, H.Q., Anga, H.M., Tadéa, M.O., Wang, S.B., 2012. Red mud and fly ash supported Co catalysts for phenol oxidation. Catal. Today 190 $68-72$.

Sarker, P.K., 2009. Analysis of geopolymer concrete columns. Mater. Struct. 42, 715-724.

Sarker, P.K., 2011. Bond strength of reinforcing steel embedded in geopolymer concrete. Mater. Struct. 44, 1021-1030.

Sarker, P.K., McKenzie, L., 2009. Strength and hydration heat of concrete using fly ash as a partial replacement. Proceedings of 24th Biennial Conference of the Concrete Institute of Australia, September 17-19, 2009, Sydney, Australia.

Sarker, P.K., Haque, R., Ramgolam, V., 2012. Fracture behaviour of heat cured fly ash based geopolymer concrete. Mater. Des. 44, 580-586.

Sarmah, M., Baruah, B.P., Khare, P., 2013. A comparison between $\mathrm{CO}_{2}$ capturing capacities of fly ash based composites of MEA/DMA and DEA/DMA. Fuel Process. Technol. 106, 490-497.
Sarode, D.B., Jadhav, R.N., Khatik, V.A., Ingle, S.T., Attarde, S.B., 2010. Extraction and leaching of heavy metals from thermal power plant fly ash and its admixtures. Pol. J. Environ. Stud. 19, 1325-1330.

Sears, L., 2011. Future trends for PFA in cementitious systems. Proceedings of 1st Future Cement Conference and Exhibition, February 8, 2011, London Chamber of Commerce and Industry, London, UK.

Seeley, F.G., McDowell, W.J., Felker, L.K., Kelmers, A.D., Egan, B.Z., 1981. Determination of extraction equilibria for several metals in the development of a process designed to recover aluminum and other metals from coal combustion ash. Hydrometallurgy 6 , 277-290.

Seo, M.W., Goo, J.H., Kim, S.D., Lee, S.H., Choi, Y.H., 2010. Gasification characteristics of coal/biomass blend in a dual circulating fluidized bed reactor. Energy Fuel 24, 3108-3118.

Shaheen, S.M., Hooda, P.S., Tsadilas, C.D., 2014. Opportunities and challenges in the use of coal fly ash for soil improvements-a review. J. Environ. Manag. 145, 249-267.

Shao, H., Liang, K.M., Zhou, F., Wang, G.L., Peng, F., 2004. Characterization of cordieritebased glass-ceramics produced from fly ash. J. Non-Cryst. Solids 337, 157-160.

Shemi, A., Mpana, R.N., Ndlovu, S., van Dyk, L.D., Sibanda, V., Seepe, L., 2012. Alternative techniques for extracting alumina from coal fly ash. Miner. Eng. 34, 30-37.

Shigemoto, N., Hayshi, H., 1993. Selective formation of Na-X zeolite from coal fly ash by fusion with sodium prior to hydrothermal reaction. J. Mater. Sci. 28, 4781-4786.

Shoumkova, A.S., 2011. Magnetic separation of coal fly ash from Bulgarian power plants. Waste Manag. Res. 29, 1078-1089.

Singh, N., 2009. Adsorption of herbicides on coal fly ash from aqueous solutions. J. Hazard. Mater. 168, 233-237.

Skousen, J., Paul Ziemkiewicz, Z., Yang, J.E., 2012. Use of coal combustion by-products in mine reclamation: review of case studies in the USA. Geosyst. Eng. 15, 71-83.

Sokolar, R., Vodova, L., 2011. The effect of fluidized fly ash on the properties of dry pressed ceramic tiles based on fly ash-clay body. Ceram. Int. 37, 2879-2885.

Sripriya, R., Rao, P.V.T., Bapat, J.P., Singh, N.P., Das, P., 2003. Development of an alternative to magnetite for use as heavy media in coal washeries. Int. J. Miner. Process. 71, $55-71$.

Sushil, S., Batra, V.S., 2006. Analysis of fly ash heavy metal content and disposal in three thermal power plants in India. Fuel 85, 2676-2679.

Tan, H.B., 2011. Preparation of mullite whiskers from coal fly ash using sodium sulfate flux. Int. J. Miner. Process. 100, 188-189.

Taylor, H.F.W., 1997. Cement Chemistry. 2nd ed. Thomas Telford, London.

Temimi, M., Camps, J.P., Laquerbe, M., 1995. Valorization of fly ash in the cold stabilization of clay materials. Resour. Conserv. Recycl. 15, 219-234.

Temuujin, J., van Riessen, A., MacKenzie, K.J.D., 2010. Preparation and characterisation of fly ash based geopolymer mortars. Constr. Build. Mater. 24, 1906-1910.

Tripathi, R.C., Jha, S.K., Ram, L.C., Vijayan, B.V., 2014. Effect of radionuclides present in lignite fly ash on soil and crop produce. J. Hazard. Toxic Radioact. Waste 18, 04014019.

Vassilev, S.V., Vassileva, C.G., 1997. Geochemistry of coals, coal ashes and combustion wastes from coal-fired power stations. Fuel Process. Technol. 51, 19-45.

Vassilev, S.V., Vassileva, C.G., 2005. Methods for characterization of composition of fly ashes from coal-fired power stations: a critical overview. Energy Fuel 19 1084-1098.

Vassilev, S.V., Menendez, R., Alvarez, D., Diaz-Somoano, M., Martinez-Tarazona, M.R. 2003. Phase-mineral and chemical composition of coal fly ashes as a basis for thei multicomponent utilization. 1. Characterization of feed coals and fly ashes. Fuel 82 , 1793-1811

Vassilev, S.V., Menendez, R., Diaz-Somoano, M., Martinez-Tarazona, R., 2004. Phasemineral and chemical composition of coal fly ashes as a basis for their multicomponent utilization. 2. Characterization of ceramic cenosphere and salt concentrates. Fuel 83, 585-603.

Wang, S.B., 2008. Application of solid ash based catalysts in heterogeneous catalysis. Environ. Sci. Technol. 42, 7055-7063.

Wang, S.M., Liang, K.M., 2007. High infrared radiance glass-ceramics obtained from fly ash and titanium slag. Chemosphere 69, 1798-1801.

Wang, C.F., Li, J.S., Wang, L.J., Sun, X.Y., 2008. Influence of NaOH concentrations on synthesis of pure-form zeolite A from fly ash using two-stage method. J. Hazard. Mater. 155, 58-64.

Wang, C.F., Li, J.S., Sun, X., Wang, L.J., Sun, X.Y., 2009. Evaluation of zeolites synthesized from fly ash as potential adsorbents for wastewater containing heavy metals. J. Environ. Sci. 21, 127-136.

Wang, M.W., Yang, J., Ma, H.W., Shen, J., Li, J.H., Guo, F., 2012. Extraction of aluminum hydroxide from coal fly ash by pre-desilication and calcination methods. Adv. Mater. Res. 396-398, 706-710.

Ward, C.R., French, D., Jankowski, J., Dubikova, M., Li, Z., Riley, K.W., 2009. Element mobility from fresh and long-stored acidic fly ashes associated with an Australian power station. Int. J. Coal Geol. 80, 224-236.

Wasekar, P.A., Kadam, P.G., Mhaske, S.T., 2012. Effect of cenosphere concentration on the mechanical, thermal, rheological and morphological properties of Nylon 6. J. Miner Mater. Charact. Eng. 11, 807-812.

Wee, J.H., 2013. A review on carbon dioxide capture and storage technology using coal fly ash. Appl. Energy 106, 143-151.

Xuan, X.P., Yue, C.T., Li, S.Y., Yao, Q., 2003. Selective catalytic reduction of NO by ammonia with fly ash catalyst. Fuel 82, 575-579.

Yang, C.H., 2000. A Study on the Resources Recovery of Coal Fly Ash. Cheng Kung University, Taiwan (Master's Dissertation).

Yao, Z.T., 2013. Generation, characterization and extracting of silicon and aluminium from coal fly ash. In: Sarker, P.K. (Ed.), Fly Ash: Sources, Applications and Potential Environmental Impacts. Nova Science Publishers, New York, pp. 3-58.

Yao, Z.T., Li, H.Y., Xia, M.S., 2009a. Hydrothermal synthesis of sodalite from coal fly ash and its property characterization. Chin. J. Nonferrous Metals 19, 366-371. 
Yao, Z.T., Xia, M.S., Ye, Y., Zhang, L., 2009b. Synthesis of zeolite Li-ABW from fly ash by fusion method. J. Hazard. Mater. 170, 639-644.

Yao, Z.T., Xia, M.S., Ye, Y., 2011a. Dilithium dialuminium trisilicate crystalline phase prepared from coal fly ash. J. Mater. Eng. Perform. 21, 877-881.

Yao, Z.T., Tan, S.H., Xia, M.S., Ye, Y., Li, J.H., 2011b. Synthesis, characterization and sintering behavior of indialite ceramic from fly ash. Waste Manag. Res. 29, 1090-1097.

Yao, Z.T., Ye, Y., Xia, M.S., 2013. Synthesis and characterization of lithium zeolites with ABW type from coal fly ash. Environ. Prog. Sustain. 32, 790-796.

Yao, Z.T., Xia, M.S., Sarker, P.K., Chen, T., 2014. A review of the alumina recovery from coal fly ash, with a focus in China. Fuel 120, 74-85.

Yavuz, C.T., Prakash, A., Mayo, J.T., Colvin, V.L., 2009. Magnetic separations: from stee plants to biotechnology. Chem. Eng. Sci. 64, 2510-2521.
Zhang, A.L., Wang, N.N., Zhou, J.T., Jiang, P., Liu, G.F., 2012. Heterogeneous Fenton-like catalytic removal of p-nitrophenol in water using acid-activated fly ash. J. Hazard. Mater. 201-202, 68-73.

Zheng, Y.J., Jensen, A.D., Windelin, J., Jensen, F., 2012. Review of technologies for mercury removal from flue gas from cement production processes. Prog. Energy Combust. Sci. 38, 599-629.

Zhou, L., Chen, Y.L., Zhang, X.H., Tian, F.M., Zu, Z.N., 2014. Zeolites developed from mixed alkali modified coal fly ash for adsorption of volatile organic compounds. Mater. Lett. 119, 140-142.

Zyryanov, V.V., Petrov, S.A., Matvienko, A.A., 2011. Characterization of spinel and magnetospheres of coal fly ashes collected in power plants in the former USSR. Fuel 90, 486-492. 